\title{
Targeting surface-layer proteins with single-domain antibodies: a potential therapeutic approach against Clostridium difficile-associated disease
}

\author{
Hiba Kandalaft ${ }^{1}$ - Greg Hussack ${ }^{1}$ - Annie Aubry ${ }^{1}$ - Henk van Faassen ${ }^{1}$. \\ Yonghong Guan $^{1} \cdot$ Mehdi Arbabi-Ghahroudi ${ }^{1,2,3} \cdot$ Roger MacKenzie $^{1,3}$. \\ Susan M. Logan ${ }^{1,4}$ • Jamshid Tanha ${ }^{1,3,4}$
}

Received: 25 February 2015 /Revised: 1 April 2015 / Accepted: 5 April 2015 / Published online: 5 May 2015

(C) The Author(s) 2015. This article is published with open access at Springerlink.com

\begin{abstract}
Clostridium difficile is a leading cause of death from gastrointestinal infections in North America. Antibiotic therapy is effective, but the high incidence of relapse and the rise in hypervirulent strains warrant the search for novel treatments. Surface layer proteins (SLPs) cover the entire C. difficile bacterial surface, are composed of highmolecular-weight (HMW) and low-molecular-weight (LMW) subunits, and mediate adherence to host cells. Passive and active immunization against SLPs has enhanced hamster survival, suggesting that antibody-mediated neutralization may be an effective therapeutic strategy. Here, we isolated a panel of SLP-specific single-domain antibodies $\left(\mathrm{V}_{\mathrm{H}} \mathrm{Hs}\right)$ using an immune llama phage display library and SLPs isolated from $C$. difficile hypervirulent strain QCD$32 \mathrm{~g} 58$ (027 ribotype) as a target antigen. Binding studies revealed a number of $\mathrm{V}_{\mathrm{H}} \mathrm{Hs}$ that bound QCD-32g58 SLPs with high affinity $\left(K_{\mathrm{D}}=3-6 \mathrm{nM}\right)$ and targeted epitopes located on the LMW subunit of the SLP. The $\mathrm{V}_{\mathrm{H}} \mathrm{Hs}$ demonstrated
\end{abstract}

This is National Research Council Canada publication 53299.

Electronic supplementary material The online version of this article (doi:10.1007/s00253-015-6594-1) contains supplementary material, which is available to authorized users.

Jamshid Tanha

jamshid.tanha@nrc-cnrc.gc.ca

1 Human Health Therapeutics Portfolio, National Research Council Canada, Ottawa, ON K1A 0R6, Canada

2 Department of Biology, Carleton University, Ottawa, ON K1S 5B6, Canada

3 School of Environmental Sciences, University of Guelph, Guelph, ON N1G 2W1, Canada

4 Department of Biochemistry, Microbiology and Immunology, University of Ottawa, Ottawa, ON K1N 6N5, Canada melting temperatures as high as $75^{\circ} \mathrm{C}$, and a few were resistant to the gastrointestinal protease pepsin at physiologically relevant concentrations. In addition, we demonstrated the binding specificity of the $\mathrm{V}_{\mathrm{H}} \mathrm{Hs}$ to the major $C$. difficile ribotypes by whole cell ELISA, where all $\mathrm{V}_{\mathrm{H}} \mathrm{Hs}$ were found to bind 001 and 027 ribotypes, and a subset of antibodies were found to be broadly cross-reactive in binding cells representative of $012,017,023$, and 078 ribotypes. Finally, we showed that several of the $\mathrm{V}_{\mathrm{H}} \mathrm{Hs}$ inhibited $C$. difficile QCD-32g58 motility in vitro. Targeting SLPs with $\mathrm{V}_{\mathrm{H}} \mathrm{Hs}$ may be a viable therapeutic approach against $C$. difficile-associated disease.

Keywords Clostridium difficile Surface layer protein · Single-domain antibody $\cdot \mathrm{V}_{\mathrm{H}} \mathrm{H} \cdot$ Nanobody

\section{Introduction}

Clostridium difficile is currently the leading hospital-acquired infection in developed countries (Karas et al. 2010). As a Gram-positive, anaerobic, endospore-forming gastrointestinal (GI) pathogen, the bacterium causes $C$. difficile-associated disease (CDAD) in humans and animals. Symptoms of CDAD range from mild antibiotic-associated diarrhea to psuedomembraneous colitis and death, with an estimated associated health care cost of $\$ 3.2$ billion annually in the USA (Dubberke and Olsen 2012; Ghantoji et al. 2010). From 2002 to 2005, the Canadian province of Québec suffered a CDAD epidemic, largely associated with a predominant strain referred to as North American pulsed-field type 1 (NAP1), ribotype 027 , toxinotype III, and restriction endonuclease group BI (Bourgault et al. 2006; Gilca et al. 2010; Hubert et al. 2007; Loo et al. 2005; Pépin et al. 2004; Warny et al. 2005). These ribotype 027 strains were undetected in 2000 
and 2001 but were responsible for the Québec outbreak in which its prevalence was estimated at $75.2 \%$ of all polymerase chain reaction (PCR)-ribotyped strains in 2003 (MacCannell et al. 2006). Québec strain QCD-32g58 (NZ_CM000287.1) is one such isolate belonging to this group. Strains within PCR ribotype 027 have evolved to produce elevated levels of toxins A and B (Dupuy et al. 2008; Warny et al. 2005), have acquired antibiotic resistance cassettes (Bourgault et al. 2006; Pépin et al. 2005; Schmidt et al. 2007; Spigaglia et al. 2008; Stabler et al. 2009), and have shown enhanced sporulation ability (Åkerlund et al. 2008), all of which contribute to their virulence. Toxins $\mathrm{A}$ and $\mathrm{B}(\mathrm{Tcd} \mathrm{A}$ and $\mathrm{TcdB})$ are the primary $C$. difficile virulence factors and are therapeutic targets (Giannasca and Warny 2004; Hussack and Tanha 2010; Jank and Aktories 2008; Jank et al. 2007); however, targeting other virulence factors such as surface layer proteins (SLPs), cell wall proteins, and flagellar components have also been proposed as therapeutic strategies (Ghose 2013).

SLPs are common to almost all Archaea and can be found in nearly every phylogenetic group within Eubacteria (Fagan and Fairweather 2014; Sleytr and Beveridge 1999). These proteins have been identified as virulence factors for bacteria such as Campylobacter fetus and Aeromonas salmonicida, providing the cells with structural integrity, acting as molecular sieves and playing a role in adherence and immune evasion (Grogono-Thomas et al. 2000; Hamadeh et al. 1995; Sara and Sleytr 2000). C. difficile produces unique SLPs in that they are cleaved from a common precursor, SlpA, to generate the HMW and LMW subunits (Calabi et al. 2001). The two subunits associate to form mature proteins that cover the entire surface of the bacterium in a para-crystalline layer. The LMW subunit is highly immunogenic (Pantosti et al. 1989), is surface exposed (Fagan et al. 2009), and exhibits low inter-strain identity among different PCR ribotypes (Calabi and Fairweather 2002; Spigaglia et al. 2011). The high variability observed could be due to a lack of functional constraints or the evolutionary need to evade host immune responses. Indeed, C. difficile SLPs play a critical role in bacterial adherence to host cells (Calabi et al. 2002; Drudy et al. 2001; Merrigan et al. 2013; Takumi et al. 1991) and thereby contribute to colonization and the persistence of infection. They have also been shown to perturb cytokine homeostasis and modulate immune responses (Ausiello et al. 2006; Bianco et al. 2011; Collins et al. 2014; Ryan et al. 2011). SLPs induce maturation of dendritic cells and the subsequent generation of a T-helper cell response through Toll-like receptor 4 (TLR4), thereby altering host inflammatory and regulatory cytokines toward an inflammatory state and contributing to the damage of the intestinal epithelium. Interestingly, human patients with relapsing $C$. difficile incidences were found to exhibit a lower immunoglobulin M ( $\operatorname{IgM}$ ) response to SLPs compared to patients with a single $C$. difficile episode (Drudy et al. 2004), suggesting that the ability to mount an anti-SLP antibody response may significantly determine a patient's disease state. Collectively, these studies support the hypothesis of an important role for SLPs in innate and adaptive immunity.

A limited number of examples suggest targeting SLPs could be a potential therapeutic approach to combat CDAD. O'Brien et al. (2005) demonstrated that prophylactic administration of SLP anti-sera significantly prolonged survival of hamsters that were lethally challenged. Subsequent studies of active immunization of mice using crude cell wall extracts showed a significant reduction in $C$. difficile colonization of the immunized group compared to controls (Péchiné et al. 2007). Currently, C. difficile infections are treated with a course of antibiotics, which can alter the composition of the gut microbiome and increase the selection pressure on the organism, which can in turn lead to antibiotic resistance. Targeting essential bacterial virulence factors, such as SLPs, is an alternative therapeutic strategy to conventional antibiotic use, which can address the risk of rising antibiotic resistance (Cegelski et al. 2008; Clatworthy et al. 2007; Lynch and Wiener-Kronish 2008).

Single-domain antibodies isolated from the variable domains of Camelidae species heavy-chain IgGs (referred to as $\mathrm{V}_{\mathrm{H}} \mathrm{Hs}$ or "Nanobodies") are attractive candidates to explore for oral therapy because these domains retain the affinity and specificity of conventional monoclonal antibodies (mAbs), but possess added biophysical advantages such as resistance to extreme $\mathrm{pH}$ and proteases (Harmsen and De Haard 2007; Holliger and Hudson 2005; Holt et al. 2003). Single-domain antibodies have been isolated to many targets in the context of infection and immunity (Hussack and Tanha 2010; Wesolowski et al. 2009), and their potential as oral therapeutics has been well documented (Harmsen et al. 2007; van der Vaart et al. 2006; Virdi et al. 2013).

The use of antibodies as neutralizing agents, in addition to studies implicating $C$. difficile SLPs as mediators for cell-host interactions (Calabi et al. 2002; Drudy et al. 2001), has inspired the current study. Here, $\mathrm{V}_{\mathrm{H}} \mathrm{Hs}$ to SLPs from C. difficile strain QCD-32g58 were selected from an immune llama $\mathrm{V}_{\mathrm{H}} \mathrm{H}$ phage display library. The antibodies were then functionally and biochemically characterized with respect to structure, affinity, specificity, aggregation state, thermostability, resistance to pepsin digestion, and the ability to bind and inhibit the motility of $C$. difficile cells.

\section{Materials and methods}

\section{Isolation of SLPs from $C$. difficile strains 630 and QCD-32g58}

C. difficile SLPs were isolated using low-pH glycine extraction as described previously (Dubreuil et al. 1988) with the following modifications. Briefly, cells from strains QCD32g58 (GenBank accession no. AAML00000000; Janvilisri 
et al. 2009; Forgetta et al. 2011) and 630 (GenBank accession no. AM180355.1; Janvilisri et al. 2009; Monot et al. 2011; Sebaihia et al. 2006) were cultured overnight on a BHI-agar plate, scraped, resuspended in $500 \mu \mathrm{l}$ of $0.2 \mathrm{M}$ glycine, $\mathrm{pH}$ 2.2 , and incubated for $10 \mathrm{~min}$ at room temperature. Bacterial cells were removed by centrifugation at $13,000 \mathrm{rpm}$ in a benchtop centrifuge and the SLP-containing supernatant transferred to a 4-ml Amicon filter device with a $5000 \mathrm{Da}$ MWCO (EMD Millipore, Toronto, ON, Canada) for buffer exchange. The SLPs were washed twice with $4 \mathrm{ml}$ of sterile $\mathrm{H}_{2} \mathrm{O}$ and collected in $1 \mathrm{ml}$ sterile $\mathrm{H}_{2} \mathrm{O}$. A 10 - $\mu$ l aliquot was mixed with SDS-PAGE loading buffer containing $\beta$ mercaptoethanol and analyzed on a $12.5 \%$ SDS-PAGE gel. Size-exclusion chromatography (SEC) was used to further purify the isolated SLP proteins after extraction. To this end, a Superdex $^{\text {TM }} 200$ 10/30 GL column (GE Healthcare, Baied'Urfé, QC, Canada) was equilibrated with running buffer (10 mM HEPES buffer, pH 7.5, $150 \mathrm{mM} \mathrm{NaCl}$ ), and $500 \mu \mathrm{l}$ of SLP extracts were loaded and eluted over one column volume as previously described (Fagan et al. 2009). Eluted fractions were analyzed on a $12.5 \%$ SDS-PAGE for content. All fractions were stored at $4{ }^{\circ} \mathrm{C}$ for later use.

\section{Llama immunization, $\mathrm{V}_{\mathrm{H}} \mathrm{H}$ phage display library construction, and panning}

Llama immunization, library construction, and panning were carried out as described previously (Hussack et al. 2012). Briefly, for llama immunization, one adult male llama (Lama glama) was immunized subcutaneously four times at its lower back with a mixture of QCD-32g58 and 630 SLP antigens at the Cedarlane animal facility (Burlington, ON, Canada) and according to the company's animal safety protocol. On the first day, a pre-immune bleed was conducted and a mixture of two antigens $(100 \mu \mathrm{g}$ of each antigen diluted in PBS in total volume of $1.25 \mathrm{ml})$ and Freund's complete adjuvant $(1.25 \mathrm{ml}$; Sigma, Oakville, ON, Canada) was injected into the llama. The llama received three additional boosts with $100 \mu \mathrm{g}$ of the same antigen mixture with Freund's incomplete adjuvant (Sigma) on days 28, 47, and 66. Blood (10-15 ml) was collected on days 59 and 72. Total (un-fractionated) serum was analyzed for a specific response to QCD-32g58 and 630 SLPs by enzyme-linked immunosorbent assay (ELISA). Llama serum from day 72 was fractionated into conventional (IgG1) and heavy-chain antibody (IgG2 and IgG3) components and analyzed for specific binding to QCD-32g58 and 630 SLPs by ELISA (Hussack et al. 2012). Lymphocytes were isolated at Cedarlane. $\mathrm{A} \mathrm{V}_{\mathrm{H}} \mathrm{H}$ phage display library was constructed using approximately $2 \times 10^{7}$ lymphocytes (as the source of $\mathrm{V}_{\mathrm{H}} \mathrm{H}$ repertoire genes) collected from the day 72 blood. The size of the library was estimated to be $2.7 \times 10^{8}$ transformants. The $\mathrm{V}_{\mathrm{H}} \mathrm{H}$ DNA fragments from 92 colonies were PCRamplified and sequenced to assess library diversity. Library phage was prepared and $10^{12}$ colony-forming units (CFU) of library phage was used as input for the first round of panning against $10 \mu \mathrm{g}$ of SEC-purified QCD-32g58 SLPs coated onto NuncMaxisorp ${ }^{\mathrm{TM}}$ wells (Thermo Fisher, Ottawa, ON, Canada). For the following three rounds of panning, $10^{11} \mathrm{CFU}$ phage was used as the input. Phage ELISA was performed to identify individual phage displaying $\mathrm{V}_{\mathrm{H}} \mathrm{Hs}$ specific to QCD-32g58 and 630.

\section{$\mathrm{V}_{\mathbf{H}} \mathrm{H}$ subcloning, soluble expression, purification, and SEC}

Positive $\mathrm{V}_{\mathrm{H}} \mathrm{H}$ binders identified by phage ELISA were subcloned, expressed in 1-1 cultures and purified by immobilized metal-ion affinity chromatography as described (Hussack et al. 2012). Purified proteins were assessed for purity and integrity by SDS-PAGE. The aggregation status and elution volumes of $\mathrm{V}_{\mathrm{H}} \mathrm{Hs}$ were determined by SEC using a Superdex ${ }^{\text {TM }} 75$ 10/300 GL column (GE Healthcare) as described (Hussack et al. 2012; Kim et al. 2012a). Elution volumes were used to determine apparent molecular masses $\left(M_{\mathrm{app}} \mathrm{s}\right)$ of $\mathrm{V}_{\mathrm{H}} \mathrm{Hs}$ from a set of protein standards (Hussack et al. 2011b). SEC chromatograms were normalized as described (Kim et al. 2012b).

\section{SPR analysis}

The binding of all $\mathrm{V}_{\mathrm{H}} \mathrm{Hs}$ to immobilized QCD-32g58 SLP, 630 SLP, and QCD-32g58 SLP LMW subunit was determined by surface plasmon resonance (SPR) using a Biacore 3000 (GE Healthcare). The SLPs were SEC-purified as described above prior to immobilization at concentrations of $50 \mu \mathrm{g} / \mathrm{ml}$ in $10 \mathrm{mM}$ acetate buffer on a CM5 sensor chip using the amine coupling kit supplied by the manufacturer (GE Healthcare). In all instances, analyses were carried out at $25{ }^{\circ} \mathrm{C}$ in $10 \mathrm{mM}$ HEPES running buffer, $\mathrm{pH} 7.4$, containing $150 \mathrm{mM} \mathrm{NaCl}$, $3 \mathrm{mM}$ EDTA, and $0.005 \%$ surfactant P20 at a flow rate of $20 \mu \mathrm{l} / \mathrm{min}$. For regeneration, the surfaces were washed thoroughly with either running buffer $\left(\mathrm{SLP}_{-} \mathrm{V}_{\mathrm{H}} \mathrm{H} 2, \mathrm{SLP}_{-} \mathrm{V}_{\mathrm{H}} \mathrm{H} 26\right.$, SLP_ $\mathrm{V}_{\mathrm{H}} \mathrm{H} 49$, and SLP_ $\left.\mathrm{V}_{\mathrm{H}} \mathrm{H} 50\right), 10 \mathrm{mM}$ glycine- $\mathrm{HCl}, \mathrm{pH}$ 3.0, for $3 \mathrm{~s}$ (SLP_ $\left.\mathrm{V}_{\mathrm{H}} \mathrm{H} 22\right), 10 \mathrm{mM}$ glycine- $\mathrm{HCl}, \mathrm{pH} 2.5$, for $3 \mathrm{~s}\left(\mathrm{SLP}_{-} \mathrm{V}_{\mathrm{H}} \mathrm{H} 5\right.$ and SLP $\left.\mathrm{V}_{\mathrm{H}} \mathrm{H} 46\right)$, or $50 \mathrm{mM} \mathrm{NaOH}$ for $3 \mathrm{~s}$ (SLP $\mathrm{V}_{\mathrm{H}} \mathrm{H} 12$ and SLP $\mathrm{V}_{\mathrm{H}} \mathrm{H} 23$ ). Due to the loss of surface activity after $50 \mathrm{mM} \mathrm{NaOH}$ surface regeneration, a fresh surface was made and used to study the binding activity of SLP $V_{\mathrm{H}} \mathrm{H} 12$ and SLP $\mathrm{V}_{\mathrm{H}} \mathrm{H} 23$. Data were analyzed with BIAevaluation 4.1 software.

\section{$T_{\mathrm{m}}$ measurements by circular dichroism spectroscopy}

The thermal unfolding profile of each antibody was obtained using circular dichroism (CD) according to a previously described method (Hussack et al. 2011b) with minor modifications. Briefly, after dialysis into $10 \mathrm{mM}$ sodium phosphate 
buffer, $\mathrm{pH} 7.0$, a 1-mm cuvette containing $200 \mu \mathrm{l}$ of a $\mathrm{V}_{\mathrm{H}} \mathrm{H}$ at $50 \mu \mathrm{g} / \mathrm{ml}$ was used to obtain CD spectra from 180-260 nm using a J-810 spectropolarimeter (Jasco Inc., Easton, MD, USA). The temperature was increased from 30 to $96{ }^{\circ} \mathrm{C}$ at a temperature ramp rate of $1{ }^{\circ} \mathrm{C} / \mathrm{min}$, and data were collected every $2{ }^{\circ} \mathrm{C}$ at a spectral scan rate of $50 \mathrm{~nm} / \mathrm{min}$ and $1-\mathrm{mm}$ bandwidth.

\section{Disulfide bond mapping by MS}

Disulfide bond mapping of SLP $\mathrm{V}_{\mathrm{H}} \mathrm{H} 22$ and SLP $\mathrm{V}_{\mathrm{H}} \mathrm{H} 50$, each with four Cys residues, was performed essentially as described (Kim et al. 2012b; Hussack et al. 2011b). Briefly, tryptic fragments for subsequent mass spectrometry (MS) analysis were prepared as described (Kim et al. 2012a). Aliquots of $\mathrm{V}_{\mathrm{H}} \mathrm{H}$ proteolytic digests were resuspended in $0.1 \%(v / v)$ formic acid (aq) and analyzed by nanoflow reversed-phase HPLC MS (nanoRPLC-ESI-MS) with datadependent analysis (DDA) using collision-induced dissociation (CID) on a nanoAcquity UPLC system coupled to a QTOF Ultima ${ }^{\mathrm{TM}}$ hybrid quadrupole/TOF mass spectrometer (Waters, Milford, MA, USA). The peptides were first loaded onto a $300 \mu \mathrm{m}$ I.D. $\times 5$ mm C18 PepMap100 $\mu$-precolumn (Thermo Fisher) and then eluted into a $100 \mu \mathrm{m}$ I.D. $\times 10 \mathrm{~cm}$ 1.7- $\mu \mathrm{m}$ BEH130C18 column (Waters) using a linear gradient from 0 to $36 \%$ solvent $\mathrm{B}$ (acetonitrile $+0.1 \%$ formic acid) over $36 \mathrm{~min}$ followed by 36-90\% solvent B for $2 \mathrm{~min}$. Solvent A was $0.1 \%$ formic acid in water. The peptide $\mathrm{MS}^{2}$ spectra were compared with $\mathrm{V}_{\mathrm{H}} \mathrm{H}$ protein sequences using the Mascot ${ }^{\mathrm{TM}}$ database searching algorithm (Matrix Science, London, UK). The $\mathrm{MS}^{2}$ spectra of the disulfide-linked peptides were de-convoluted using the MaxEnt 3 program (Waters) for de novo sequencing to confirm and/or determine the exact disulfide linkage positions.

\section{Pepsin digestion assay}

To assess the degree of resistance of each antibody to pepsin (a common protease in the digestive tract), SLP-specific $\mathrm{V}_{\mathrm{H}} \mathrm{Hs}$ were subjected to pepsin digestion as previously described (Hussack et al. 2011b) at enzyme concentrations ranging from 1.25 to $100 \mu \mathrm{g} / \mathrm{ml}$. Triplicate independent experiments were conducted, and densitometry analysis values were averaged to determine percent pepsin resistance.

\section{Epitope characterization by Western blot analysis}

To determine subunit specificity of the $\mathrm{V}_{\mathrm{H}} \mathrm{Hs}$ and the nature of their epitope (conformational or linear), denaturing Western blots of strain QCD-32g58 SLPs were probed with anti-SLP $\mathrm{V}_{\mathrm{H}} \mathrm{Hs}$. SLPs $(5 \mu \mathrm{g} /$ lane $)$ were separated on $12.5 \% \mathrm{SDS}-$ PAGE gels and transferred to PVDF membranes at $100 \mathrm{~V}$ for $1 \mathrm{~h}$. Membranes were blocked for $2 \mathrm{~h}$ with $2 \%(w / v)$ milk in PBS and probed with various $\mathrm{V}_{\mathrm{H}} \mathrm{Hs}(50 \mu \mathrm{g} / 5 \mathrm{ml}$ PBS-T $[\mathrm{PBS} / 0.05 \%(v / v)$ Tween 20]) for $1 \mathrm{~h}$. Membranes were washed three times in PBS-T followed by addition of mouse anti-His IgG-alkaline phosphatase (AP) conjugate (Abcam, Cambridge, MA, USA), diluted 1:5000 in blocking buffer, for $1 \mathrm{~h}$. Membranes were washed as before and subjected to AP substrate (Bio-Rad, Mississauga, ON, Canada) for $10 \mathrm{~min}$, washed in distilled $\mathrm{H}_{2} \mathrm{O}$ and air dried. A corresponding stained SDS-PAGE gel of the SLPs was used as reference.

\section{Whole cell ELISA}

C. difficile strains were grown on BHI supplemented agar under anaerobic conditions at $37{ }^{\circ} \mathrm{C}$ overnight. Cells were resuspended in PBS containing $3 \%(v / v)$ formalin and left for $24 \mathrm{~h}$ at $4{ }^{\circ} \mathrm{C}$. Cells were washed two times with PBS and resuspended to $\mathrm{OD}_{600}$ 0.08. NuncMaxiSorp ${ }^{\circledR}$ Flat-Bottom plates were coated with $100 \mu$ of formalin-fixed cells overnight at $37{ }^{\circ} \mathrm{C}$. Plates were blocked with $2 \%(w / v)$ milk in PBS. His ${ }_{6}$-tagged $\mathrm{V}_{\mathrm{H}} \mathrm{Hs}$ specific for SLP were then added $\left(10 \mu \mathrm{g} / \mathrm{ml}\right.$ in PBS-T) and plates incubated at $37^{\circ} \mathrm{C}$ for $1 \mathrm{~h}$ in a shaker incubator. Plates were washed three times with PBS-T and then incubated with rabbit anti-His ${ }_{6}$ antibody-horse radish peroxidase conjugate (1:5,000 in PBS-T, of a $1 \mathrm{mg} / \mathrm{ml}$ stock; Cedarlane) for $1 \mathrm{~h}$ at $37^{\circ} \mathrm{C}$. Following washing as above, the antibody was detected with TMB substrate for $10 \mathrm{~min}$ and the reaction stopped with $1 \mathrm{M} \mathrm{H}_{3} \mathrm{PO}_{4}$. Samples were analyzed in triplicate, and the absorbance was measured at $450 \mathrm{~nm}$.

\section{Motility assay}

An in vitro motility assay was used to determine if the isolated $\mathrm{V}_{\mathrm{H}} \mathrm{Hs}$ were capable of binding whole $C$. difficile cells and preventing motility. Sterile culture tubes containing $5 \mathrm{ml}$ $0.175 \%$ agar-BHI media supplemented with $0.5 \%(w / v)$ Bacto-yeast extract, $0.12 \%(w / v) \mathrm{NaCl}$, and 25 or $50 \mu \mathrm{g} / \mathrm{ml}$ $\mathrm{V}_{\mathrm{H}} \mathrm{H}$, were stabbed with a fresh culture of strain QCD-32g58 as previously described (Twine et al. 2009) and incubated in anaerobic conditions at $37{ }^{\circ} \mathrm{C}$ for $23 \mathrm{~h}$. Photographs were taken at $23 \mathrm{~h}$ postinoculation to monitor the effects of each antibody on motility of the strain relative to a control which did not receive antibody.

\section{Results}

\section{Purification of SLPs from 630 and QCD-32g58 C. difficile strains}

SLPs from C. difficile strains 630 and QCD-32g58 (Figs. 1a and $\mathrm{S} 1$ ) were first purified by low $\mathrm{pH}$ glycine extraction. When analyzed by reducing SDS-PAGE, the HMW and 


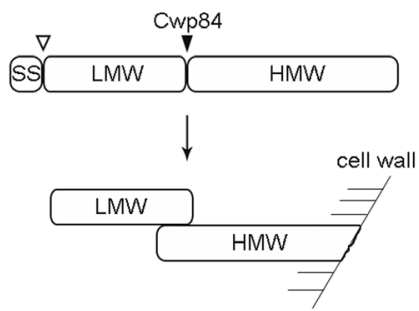

b

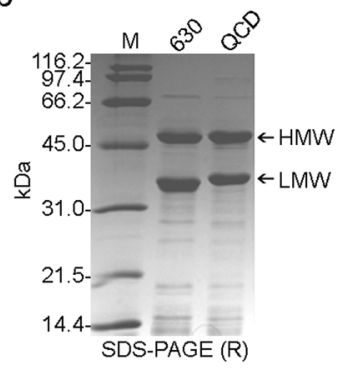

C

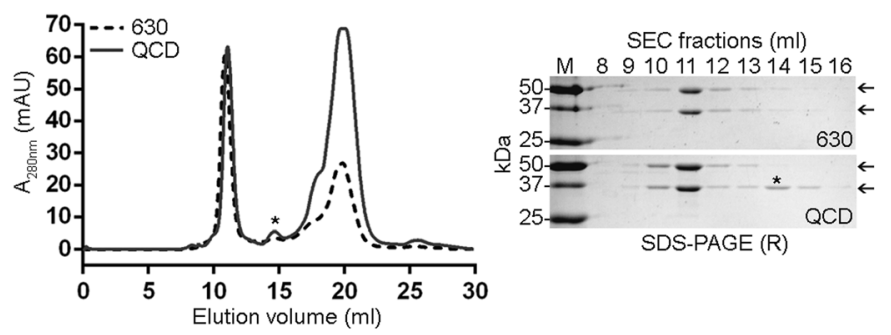

e

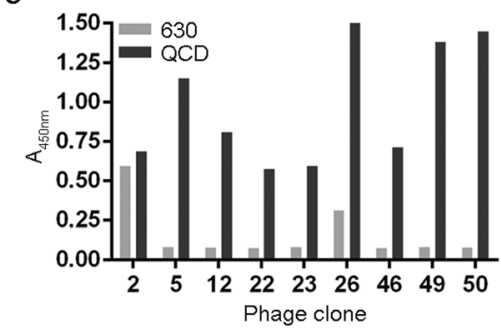

$f$

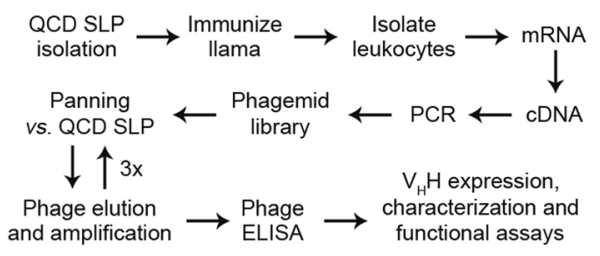

\begin{tabular}{|c|c|}
\hline Day & Event \\
\hline 0 & Pre-immune bleed \\
\hline 0 & Immunize $(100 \mu \mathrm{g} \mathrm{Ag}$ in FCA $)$ \\
\hline 28 & Boost \#1 (100 $\mu \mathrm{g} \mathrm{Ag}$ in FIA $)$ \\
\hline 47 & Boost \#2 $(100 \mu \mathrm{g} \mathrm{Ag}$ in FIA $)$ \\
\hline 59 & Immune bleed \#1 \\
\hline 66 & Boost \#3 $(100 \mu \mathrm{g} \mathrm{Ag}$ in FIA $)$ \\
\hline 72 & Immune bleed \#2 \\
\hline
\end{tabular}

Phage clone

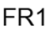

CDR1

${ }_{42} \mathrm{FR}_{495052}{ }_{55} \mathrm{CDR} 2$

FR3

CDR3

FR4

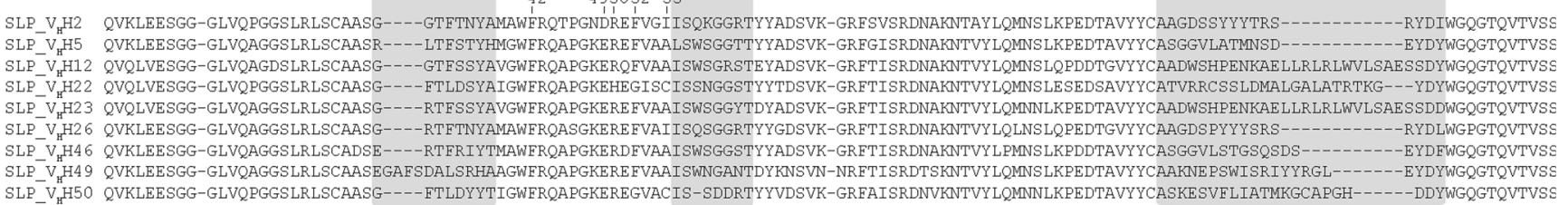

g

DSB 23-55

DSB 55-CDR3

SLP_V DSB 23-CDR3

DSB 55-104

SLP_V ${ }_{\mathrm{H}} \mathrm{H} 50$ QVKLEESGG-GLVQPGGSLRLSCAASG----ETLDYYTIGWFRQAPGKEREGVACIS-SDDRTYYVDSVK-GRFAISRDNVKNTVYLQMNNLKPEDTAVYYCASKESVFLIATMKGCAPGH------DDYWGQGTQVTVSE

Fig. 1 Isolation of SLP-specific $\mathrm{V}_{\mathrm{H}} \mathrm{Hs}$. a Schematic diagram of C. difficile S-layer proteins. Top, SLP low-molecular-weight (LMW) and high-molecular-weight (HMW) subunits are expressed as a single polypeptide chain before cleavage with Cwp84 cysteine protease. The cleavage site of the signal sequence (SS) is also shown. Bottom, after Cwp84-mediated cleavage, the LMW and HMW subunits associate in the orientation relative to the bacterial cell wall shown. b SDS-PAGE, run under reducing $(\mathrm{R})$ conditions, of SLPs purified from 630 and $\mathrm{QCD}-$ 32g58 (QCD) strains using low pH extraction. c Left, SEC Superdex ${ }^{\mathrm{TM}}$ 200 profile of SLPs and, right, reducing SDS-PAGE gel of the corresponding fractions. Only LMW subunit from QCD-32g58 could

LMW SLPs migrated to $\sim 45$ and $\sim 33 \mathrm{kDa}(630)$ and $\sim 45$ and $\sim 34 \mathrm{kDa}$ (QCD-32g58) (Fig. 1b), which is close to the predicted $M \mathrm{~s}$ of 39.5/34.2 kDa and 44.2/33.9 $\mathrm{kDa}$ (HMW/LMW SLPs, from 630 and QCD-32g58 strains, respectively) and consistent with others who ran SLPs under reducing SDSPAGE conditions (Calabi et al. 2001; Mauri et al. 1999). To increase SLP purity, low $\mathrm{pH}$ extracted-SLP preparations were injected over a Superdex ${ }^{\mathrm{TM}} 200$ SEC column (Fig. 1c, left panel). Fractions from the two major peaks and one minor peak were analyzed by $12.5 \%$ SDS-PAGE (Fig. 1c, right panel). The first peak (with an elution volume of $10.8 \mathrm{ml}$ ), when analyzed by SDS-PAGE, confirmed the presence of be purified (shown with an asterisk). The HMW subunit could not be purified from either strain. d Work flow overview and llama immunization schedule for the isolation of SLP-specific $\mathrm{V}_{\mathrm{H}} \mathrm{Hs}$. FCA Freund's complete adjuvant, FIA Freund's incomplete adjuvant, $A g$ QCD-32g58 SLP. e Phage ELISA demonstrating the binding of phagedisplayed $\mathrm{V}_{\mathrm{H}} \mathrm{Hs}$ to immobilized SLPs. f Amino acid sequence alignment of $\mathrm{V}_{\mathrm{H}} \mathrm{Hs}$ isolated from panning that were expressed and characterized in this study. Positions $42,49,50,52$, and 55 are numbered. Numbering and CDR designations are according to IMGT (http://imgt.cines.fr/). $\mathbf{g}$ Unusual disulfide bonds (DSB) identified in SLP_ $\mathrm{V}_{\mathrm{H}} \mathrm{H} 22$ and SLP $\mathrm{V}_{\mathrm{H}} \mathrm{H} 50$ by mass spectrometry fingerprinting analysis

both HMW and LMW subunits of SLPs. The second minor peak eluting at approximately $15 \mathrm{ml}$ corresponded to the LMW subunit. The LMW subunit could only be isolated from QCD-32g58. The last major SEC peak was not detectable on SDS-PAGE despite the strong $A_{280 n m}$ signal, which could represent breakdown products of the HMW subunit, as it is unstable once separated from the LMW subunit (Fagan et al. 2009), and since the HMW subunit was not isolated in freeform from any of the fractions collected. The SECpurified QCD-32g58 SLP and LMW SLP were used in library panning and SPR experiments. 


\section{Llama immunization, library construction, and panning for SLP-binding $\mathrm{V}_{\mathrm{H}} \mathrm{Hs}$}

$\mathrm{V}_{\mathrm{H}} \mathrm{Hs}$ isolated from naive libraries tend to have low target antigen affinities $\left(K_{\mathrm{D}} \mathrm{S}\right.$ in the $\mu \mathrm{M}$ range; Tanha et al. 2002; Yau et al. 2005); therefore, an immune llama library was constructed to isolate high affinity binders to SLPs, using a mixture of 630 and QCD-32g58 SLPs as immunogens. A male llama was immunized using an equal mixture of both antigens, according to the schedule in Fig. 1d. Llama sera and blood were processed and a heavy-chain IgG response to QCD32g58 SLP was determined by ELISA (data not shown). An immune phage display library was constructed and was subjected to four rounds of panning against SLPs from QCD32g58 (Fig. 1d). To identify QCD-32g58-specific binders after three rounds of panning, a total of 50 TG1 E. coli colonies containing the phagemid vector were picked at random for monoclonal phage ELISA to identify binders to QCD-32g58 SLP (data not shown). Nine unique $\mathrm{V}_{\mathrm{H}} \mathrm{Hs}$ were identified, and the phage ELISA is shown for those clones (Fig. 1e). The amino acid sequence composition of the nine unique antibodies (Fig. 1f) confirmed their identity as $\mathrm{V}_{\mathrm{H}} \mathrm{Hs}\left(\right.$ not $\mathrm{V}_{\mathrm{H}} \mathrm{s}$ ), according to characteristic camelid $\mathrm{V}_{\mathrm{H}} \mathrm{H}$ residues at positions 42, 49, 50, and 52 (Harmsen et al. 2000). The $\mathrm{V}_{\mathrm{H}} \mathrm{Hs}$ were denoted SLP_ $\mathrm{V}_{\mathrm{H}} \mathrm{H} 2, \mathrm{SLP} \mathrm{V}_{\mathrm{H}} \mathrm{H} 5, \mathrm{SLP}_{-} \mathrm{V}_{\mathrm{H}} \mathrm{H} 12$, SLP_V ${ }_{H} H 22$, SLP_V ${ }_{H} H 23, S L P \_V_{H} H 26$, SLP_V ${ }_{H} H 46$, SLP_ $\mathrm{V}_{\mathrm{H}} \mathrm{H} 49$, and SLP_V $\mathrm{H}_{\mathrm{H}} \mathrm{H} 50$ (Fig. 1f). Based on the phage ELISA (Fig. 1e), all nine clones showed specific binding to SLP from QCD-32g58 while only SLP_ $\mathrm{V}_{\mathrm{H}} \mathrm{H} 2$, and less strongly SLP $\mathrm{V}_{\mathrm{H}} \mathrm{H} 26$, cross-reacted to SLP from strain 630. This is not surprising as the $\mathrm{V}_{\mathrm{H}} \mathrm{H}$ library was panned against QCD-32g58. The CDR3 length distribution among the nine antibodies isolated varied. SLP $\mathrm{V}_{\mathrm{H}} \mathrm{H} 2, \mathrm{SLP}_{-} \mathrm{V}_{\mathrm{H}} \mathrm{H} 5$, and SLP_ $V_{H} H 26$ have the shortest CDR3 with 16 residues. SLP_V $V_{H} H 12$, SLP_V $\mathrm{H}_{\mathrm{H}} \mathrm{H} 22$, and SLP_ $\mathrm{V}_{\mathrm{H}} \mathrm{H} 23$ all have a significantly long CDR3, with lengths of 28,25 , and 28 residues, respectively. Many of the clones shared high sequence homology, while SLP_ $\mathrm{V}_{\mathrm{H}} \mathrm{H} 22$ and SLP_ $\mathrm{V}_{\mathrm{H}} \mathrm{H} 50$ contained an additional cysteine residues at position 55 and in complementaritydetermining region 3 (CDR3). The presence of a cysteine at residue 55 is characteristic of $\mathrm{V}_{\mathrm{H}} \mathrm{H}$ subfamilies 3 and 4 (Harmsen et al. 2000). These two $\mathrm{V}_{\mathrm{H}} \mathrm{Hs}$ were the only binders to belong to the $\mathrm{V}_{\mathrm{H}} \mathrm{H}$ subfamily 3 while the other $\mathrm{V}_{\mathrm{H}} \mathrm{Hs}$ were subfamily 1 . Cys55 and CDR3 Cys have the potential to form an interloop disulfide bond to restrict the fold of the relatively long CDR3 and enhance the stability of the antibodies (Govaert et al. 2012; Kim et al. 2014). This indeed was shown to be the case for both SLP $\mathrm{V}_{\mathrm{H}} \mathrm{H} 22$ and SLP $\mathrm{V}_{\mathrm{H}} \mathrm{H} 50$ by MSbased disulfide bond mapping experiments (Fig. 1g; Table S1). However, and unexpectedly, disulfide bond mapping also revealed that these noncanonical Cys residues were also involved in forming other, unusual disulfide linkages. In SLP_V ${ }_{\mathrm{H}} \mathrm{H} 22$, Cys55 and CDR3 Cys form disulfide linkages with Cys23, which typically forms a highly conserved disulfide linkage with Cys 104 in $\mathrm{V}_{\mathrm{H}} \mathrm{Hs}$, and similarly in SLP $\mathrm{V}_{\mathrm{H}} \mathrm{H} 50$, Cys55 forms a disulfide linkage with Cys 104.

\section{Expression and biophysical characterization of SLP-binding $\mathrm{V}_{\mathrm{H}} \mathrm{Hs}$}

The nine SLP-binding $\mathrm{V}_{\mathrm{H}} \mathrm{Hs}$ isolated from panning were subcloned, expressed, and purified. We observed high and variable expression yields of the clones $(15-75 \mathrm{mg} / 1$ of bacterial culture). Purified $\mathrm{V}_{\mathrm{H}} \mathrm{Hs}$ were subjected to SEC analysis, and all were nonaggregating monomers as expected, with a mean $\pm \mathrm{SD} M_{\text {app }}$ of $15.9 \pm 2.4$, similar to the mean \pm SD theoretical mass of $16.3 \pm 0.6$ expected for monomeric $\mathrm{V}_{\mathrm{H}} \mathrm{Hs}$ (Fig. S2a; Table 1). We further characterized the panel of $\mathrm{V}_{\mathrm{H}} \mathrm{Hs}$ by determining midpoint unfolding temperatures $\left(T_{\mathrm{m}} \mathrm{s}\right)$ by $\mathrm{CD}$ spectroscopy and $\mathrm{V}_{\mathrm{H}} \mathrm{H}$ sensitivities to the major gastrointestinal enzyme pepsin by proteolytic digestion assays. Both techniques provide valuable information on $\mathrm{V}_{\mathrm{H}} \mathrm{H}$ stability and aid in the selection of lead candidates. From the heat-induced unfolding curves, the $\mathrm{V}_{\mathrm{H}} \mathrm{H} T_{\mathrm{m}} \mathrm{s}$ ranged from 62.3 to $75.4{ }^{\circ} \mathrm{C}$ (Fig. S2b; Table 1) with all $\mathrm{V}_{\mathrm{H}} \mathrm{Hs}$ folded at physiological temperatures. Antibody unfolding followed a single phase transition as expected. Next, all $\mathrm{V}_{\mathrm{H}} \mathrm{Hs}$ were subjected to a pepsin digestion assay at $\mathrm{pH} 2.0$, beginning with a biologically relevant concentration of pepsin at $100 \mu \mathrm{g} / \mathrm{ml}$ (Fig. S3). Under digestion conditions, the $\mathrm{V}_{\mathrm{H}} \mathrm{Hs}$ exhibited a loss of the C-terminal tag, consistent with our previous findings (Hussack et al. 2011b; To et al. 2005), and therefore lower bands corresponding to a $M$ that is $\sim 2 \mathrm{kDa}$ less than the band corresponding to the full-length $\mathrm{V}_{\mathrm{H}} \mathrm{H}$ are considered as resistant to enzymatic digestion. As expected, resistance to pepsin decreased as a function of enzyme concentration (Table 1; Fig. S3). High pepsin resistance was observed at lower pepsin concentrations and the majority of $\mathrm{V}_{\mathrm{H}} \mathrm{Hs}$ (five out of nine) showed moderate to high resistance at $25 \mu \mathrm{g} / \mathrm{ml}$ pepsin concentration. SLP_ $\mathrm{V}_{\mathrm{H}} \mathrm{H} 2$ and SLP_ $\mathrm{V}_{\mathrm{H}} \mathrm{H} 22$ showed the greatest pepsin resistance with an average of $12 \pm 3.1 \%$ and $19.6 \pm$ $0.8 \% \mathrm{~V}_{\mathrm{H}} \mathrm{H}$ remaining after digestion for $1 \mathrm{~h}$ with $100 \mu \mathrm{g} / \mathrm{ml}$ of enzyme, respectively (Table 1). At lower pepsin concentrations $(50 \mu \mathrm{g} / \mathrm{ml}), 15.3 \pm 5.0 \%$ of SLP_V $\mathrm{V}_{\mathrm{H}} \mathrm{H} 2,46.5 \pm 10.0 \%$ of SLP_ $\mathrm{V}_{\mathrm{H}} \mathrm{H} 22,21.9 \pm 9.8 \%$ of SLP_V $\mathrm{V}_{\mathrm{H}} \mathrm{H} 23$ and $2.8 \pm 2.0 \%$ of SLP_ $\mathrm{V}_{\mathrm{H}} \mathrm{H} 12$ remained undigested after $1 \mathrm{~h}$.

\section{Binding analysis of $\mathrm{V}_{\mathrm{H}} \mathrm{Hs}$ to SLPs}

For affinity determination, monomeric fractions of $\mathrm{V}_{\mathrm{H}} \mathrm{Hs}$ collected from the SEC column were analyzed by SPR. $\mathrm{V}_{\mathrm{H}} \mathrm{Hs}$ were injected over CM5-immobilized and SEC-purified QCD-32g58 SLP, 630 SLP, and the QCD-32g58 LMW subunit, at various concentrations to characterize the binding specificity and affinity (Fig. 2a, b). In the first experiment, all nine $\mathrm{V}_{\mathrm{H}} \mathrm{Hs}$ were shown to bind QCD-32g58 SLP 
Table 1 Summary of $\mathrm{V}_{\mathrm{H}} \mathrm{H}$ molecular mass, thermal stability, and pepsin resistance data

\begin{tabular}{|c|c|c|c|c|c|c|}
\hline \multirow[t]{2}{*}{$\mathrm{V}_{\mathrm{H}} \mathrm{H}$} & \multirow[t]{2}{*}{$M(\mathrm{kDa})$} & \multirow[t]{2}{*}{$M_{a p p}(\mathrm{kDa})$} & \multirow[t]{2}{*}{$T_{\mathrm{m}}\left({ }^{\circ} \mathrm{C}\right)$} & \multicolumn{3}{|c|}{ Pepsin resistance $(\%)^{\mathrm{a}}$} \\
\hline & & & & $100 \mu \mathrm{g} / \mathrm{ml}$ & $10 \mu \mathrm{g} / \mathrm{ml}$ & $1.25 \mu \mathrm{g} / \mathrm{ml}$ \\
\hline $\mathrm{SLP}_{-} \mathrm{V}_{\mathrm{H}} \mathrm{H} 2$ & 15.71 & 14.5 & 62.3 & $12.0 \pm 3.1$ & $55.3 \pm 13.1$ & $99.0 \pm 1.3$ \\
\hline $\mathrm{SLP}_{-} \mathrm{V}_{\mathrm{H}} \mathrm{H} 5$ & 15.61 & 14.2 & 70.3 & 0 & $10.3 \pm 1.5$ & $76.1 \pm 15$ \\
\hline SLP_V ${ }_{\mathrm{H}} \mathrm{H} 12$ & 17.00 & 16.6 & 73.7 & 0 & $77.8 \pm 3.9$ & $99.4 \pm 1.9$ \\
\hline $\mathrm{SLP}_{-} \mathrm{V}_{\mathrm{H}} \mathrm{H} 22$ & 16.38 & 17.3 & 74.6 & $19.6 \pm 0.8$ & $83.1 \pm 3.3$ & $99.0 \pm 1.5$ \\
\hline SLP_V ${ }_{H} H 23$ & 17.02 & 19.1 & 75.4 & 0 & $93.4 \pm 5.9$ & $97.2 \pm 1.7$ \\
\hline SLP_V ${ }_{H} H 26$ & 15.72 & 14.2 & 71.9 & 0 & $50.8 \pm 2.5$ & $96.6 \pm 0.1$ \\
\hline SLP_V ${ }_{\mathrm{H}} \mathrm{H} 46$ & 15.83 & 16.6 & 66.3 & 0 & $55.6 \pm 4.5$ & $96.6 \pm 1.6$ \\
\hline SLP_V ${ }_{H} H 49$ & 16.71 & 11.9 & 64.8 & 0 & 0 & $59.7 \pm 14.2$ \\
\hline SLP-V ${ }_{\mathrm{H}} \mathrm{H} 50$ & 16.25 & 18.7 & 70.3 & 0 & $15.9 \pm 7.9$ & $89.9 \pm 3.1$ \\
\hline
\end{tabular}

$M$ theoretical (formula) molecular mass, $M_{\text {app }}$ apparent molecular mass determined by SEC, $T_{\mathrm{m}}$ melting temperature

${ }^{a}$ Percent $\mathrm{V}_{\mathrm{H}} \mathrm{H}($ mean $\pm \mathrm{SE})$ remaining after digestion for $1 \mathrm{~h}$ at $37^{\circ} \mathrm{C}$ and $\mathrm{pH} 2.0$ with 100,10 , or $1.25 \mu \mathrm{g} / \mathrm{ml}$ of pepsin $(n=3)$

(Fig. 2a; Table 2). None of the $\mathrm{V}_{\mathrm{H}} \mathrm{Hs}$ bound to the reference surface on which a similar amount of a control protein was immobilized (data not shown). $K_{\mathrm{D}} \mathrm{S}$ were determined from kinetic rate constants $\left(\mathrm{SLP}_{-} \mathrm{V}_{\mathrm{H}} \mathrm{H} 5, \mathrm{SLP}_{-} \mathrm{V}_{\mathrm{H}} \mathrm{H} 12\right.$, SLP_ $V_{H} H 23$, and SLP_ $\left.V_{H} H 46\right)$ or by steady-state analysis (SLP_V V ${ }_{\mathrm{H}} \mathrm{H} 2, \mathrm{SLP} \mathrm{V}_{\mathrm{H}} \mathrm{H} 22$, SLP_V $\mathrm{H}_{\mathrm{H}} \mathrm{H} 26, \mathrm{SLP} \mathrm{V}_{\mathrm{H}} \mathrm{H} 49$, and SLP_ $\left.\mathrm{V}_{\mathrm{H}} \mathrm{H} 50\right)$. The $\mathrm{V}_{\mathrm{H}} \mathrm{Hs}$ SLP_ $\mathrm{V}_{\mathrm{H}} \mathrm{H} 5$, SLP_ $\mathrm{V}_{\mathrm{H}} \mathrm{H} 12$, SLP_ $V_{H} H 23$, and SLP_ $V_{H} H 46$ had the highest affinities to QCD-32g58 SLP $\left(K_{\mathrm{D}}^{-}\right.$of $\left.3-6 \mathrm{nM}\right)$. SLP_ $\mathrm{V}_{\mathrm{H}} \mathrm{H} 12$ and SLP_ $\mathrm{V}_{\mathrm{H}} \mathrm{H} 23$ required the use of $50 \mathrm{mM} \mathrm{NaOH}$ for their complete dissociation from the QCD-32g58 SLP surface, which resulted in loss of surface activity; therefore, a fresh surface was made, and only a single injection of each was used to analyze the binding activity of these two $\mathrm{V}_{\mathrm{H}} \mathrm{Hs}$. SLP_ $\mathrm{V}_{\mathrm{H}} \mathrm{H} 49$ and SLP_ $\mathrm{V}_{\mathrm{H}} \mathrm{H} 50$ had affinities of 48 and $75 \mathrm{nM}$, respectively. SLP_V ${ }_{\mathrm{H}} \mathrm{H} 2$, SLP_V $\mathrm{H}_{\mathrm{H}} \mathrm{H} 22$, and SLP_V $\mathrm{H}_{\mathrm{H}} \mathrm{H} 26$ had the weakest affinities to QCD-32g58 SLP with $K_{\mathrm{D}} \mathrm{S}$ of 230,180 , and $580 \mathrm{nM}$, respectively. These three $\mathrm{V}_{\mathrm{H}} \mathrm{Hs}$, as well as SLP_ $\mathrm{V}_{\mathrm{H}} \mathrm{H} 49$, showed a complex binding pattern to QCD-32g58 SLP in that at low antibody concentrations, high-affinity binding was observed, while at high antibody concentrations lower affinity binding was observed, which maybe an indicator of antigen heterogeneity. Collectively, the SPR data confirmed the ability of the $\mathrm{V}_{\mathrm{H}} \mathrm{Hs}$ to bind QCD-32g58 SLP.
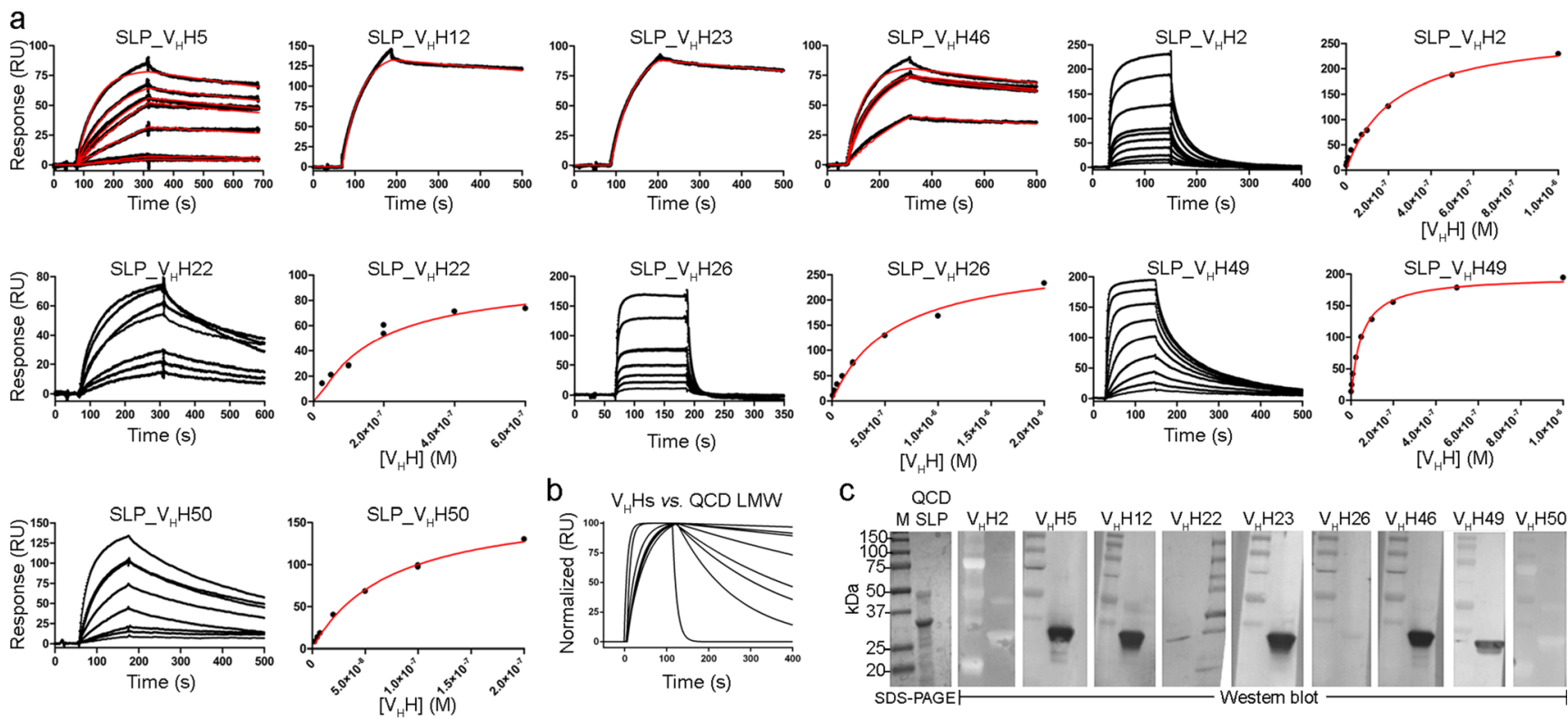

b V V Hs vs. QCD LMW
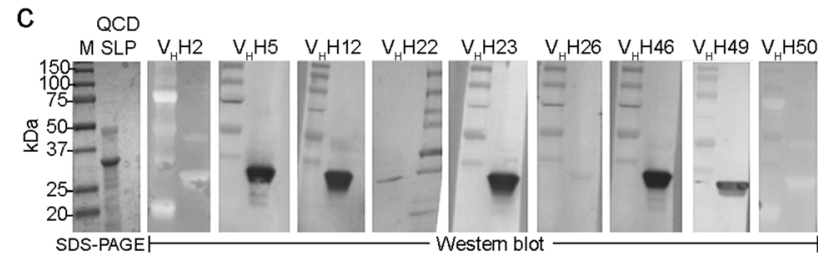

of $\mathrm{V}_{\mathrm{H}} \mathrm{Hs}$ recognizes a liner epitope on the LMW subunit of QCD-32g58 SLP. $Q C D$ QCD-32g58

Fig. 2 Characterization of $\mathrm{V}_{\mathrm{H}} \mathrm{H}$ binding to SLPs. a, b SPR sensorgrams QCD-32g58 LMW SLP (b). c Western blots demonstrating that a subset 
Table 2 SLP-specific $\mathrm{V}_{\mathrm{H}} \mathrm{H}$ binding data

\begin{tabular}{|c|c|c|c|c|c|c|c|c|}
\hline \multirow[t]{2}{*}{$\mathrm{V}_{\mathrm{H}} \mathrm{H}$} & \multicolumn{4}{|c|}{ QCD-32g58 SLP } & \multicolumn{4}{|c|}{ QCD-32g58 LMW SLP ${ }^{\mathrm{a}}$} \\
\hline & $k_{\mathrm{on}}(/ \mathrm{M} / \mathrm{s})$ & $k_{\mathrm{off}}(/ \mathrm{s})$ & $K_{\mathrm{D}}(\mathrm{nM})$ & $\mathrm{R}_{\max }(\mathrm{RU})$ & $k_{\text {on }}(/ \mathrm{M} / \mathrm{s})$ & $k_{\text {off }}(/ \mathrm{s})$ & $K_{\mathrm{D}}(\mathrm{nM})$ & $\mathrm{R}_{\max }(\mathrm{RU})$ \\
\hline $\mathrm{SLP}_{-} \mathrm{V}_{\mathrm{H}} \mathrm{H} 2$ & n.d. ${ }^{b}$ & n.d. ${ }^{b}$ & 230 & 277 & $1.5 \times 10^{5}$ & $1.3 \times 10^{-2}$ & 90 & 26 \\
\hline SLP_V $\mathrm{H}_{\mathrm{H}} \mathrm{H} 5$ & $8.2 \times 10^{4}$ & $4.6 \times 10^{-4}$ & 6 & 100 & $1.4 \times 10^{5}$ & $4.1 \times 10^{-4}$ & 3 & 151 \\
\hline SLP_V ${ }_{\mathrm{H}} \mathrm{H} 12$ & $1.2 \times 10^{5}$ & $3.4 \times 10^{-4}$ & 3 & 142 & $1.4 \times 10^{5}$ & $1.2 \times 10^{-4}$ & 1 & 131 \\
\hline SLP_V ${ }_{H} H 22$ & n.d. ${ }^{b}$ & n.d. ${ }^{\mathrm{b}}$ & 180 & 100 & $1.3 \times 10^{5}$ & $1.1 \times 10^{-3}$ & 8 & 114 \\
\hline SLP_V ${ }_{H} H 23$ & $9.4 \times 10^{4}$ & $3.7 \times 10^{-4}$ & 4 & 98 & $1.1 \times 10^{5}$ & $3.2 \times 10^{-4}$ & 3 & 72 \\
\hline SLP_V ${ }_{H} H 26$ & n.d. ${ }^{\mathrm{b}}$ & n.d. ${ }^{\mathrm{b}}$ & 580 & 288 & $2.1 \times 10^{5 \mathrm{c}}$ & $9.7 \times 10^{-2 \mathrm{c}}$ & $460^{\mathrm{c}}$ & $5^{\mathrm{c}}$ \\
\hline SLP_V ${ }_{H} H 46$ & $1.1 \times 10^{5}$ & $3.4 \times 10^{-4}$ & 3 & 83 & $1.5 \times 10^{5}$ & $3.2 \times 10^{-4}$ & 2 & 181 \\
\hline SLP_V ${ }_{H} H 49$ & n.d. ${ }^{\mathrm{b}}$ & n.d. ${ }^{\mathrm{b}}$ & 48 & 197 & $5.9 \times 10^{5}$ & $1.2 \times 10^{-2}$ & 20 & 231 \\
\hline SLP-V ${ }_{\mathrm{H}} \mathrm{H} 50$ & n.d. ${ }^{\mathrm{b}}$ & n.d. ${ }^{\mathrm{b}}$ & 75 & 175 & $1.9 \times 10^{5}$ & $2.7 \times 10^{-3}$ & 14 & 154 \\
\hline
\end{tabular}

${ }^{\text {a }}$ Binding kinetics were determined from $200 \mathrm{nM} \mathrm{V} \mathrm{V}_{\mathrm{H}} \mathrm{H}$ injections as a binding screen

${ }^{\mathrm{b}}$ A steady-state model was used to obtain the $K_{\mathrm{D}}$. Therefore, rate constants are not determined (n.d.)

${ }^{\mathrm{c}}$ The affinity and rate constants should be interpreted with caution as the experimental $\mathrm{R}_{\max }$ is very low, and multiple injection are required to confirm the values

Next, we expanded our SPR analyses to determine if the $\mathrm{V}_{\mathrm{H}} \mathrm{Hs}$ cross-reacted to $630 \mathrm{SLP}$. In a similar approach to the QCD-32g58 SLP, 630 SLP were immobilized on a CM5 sensor chip and $\mathrm{V}_{\mathrm{H}} \mathrm{Hs}$ injected at various concentrations. Consistent with our earlier phage ELISA results (Fig. 1e), only SLP_V $\mathrm{V}_{\mathrm{H}} \mathrm{H} 2$ and SLP_V $\mathrm{V}_{\mathrm{H}} \mathrm{H} 26$ bound 630 SLP (data not shown). The affinities of SLP_ $\mathrm{V}_{\mathrm{H}} \mathrm{H} 2$ and SLP_ $\mathrm{V}_{\mathrm{H}} \mathrm{H} 26$ to 630 SLP were 1 and $2 \mu \mathrm{M}$, respectively, indicating a $\sim 5$-fold weaker binding affinity to 630 SLP than QCD-32g58 SLP.

Finally, we set out to explore the nature of the QCD-32g58 SLP epitope recognized by the $\mathrm{V}_{\mathrm{H}} \mathrm{Hs}$, specifically if they bound the HMW or LMW SLP subunit. As previously shown (Fig. 1c), we were unable to purify the HMW SLP subunit and purified only a small amount of the QCD-32g58 LMW SLP subunit which limited our SPR analysis against the LMW SLP to a single concentration screen. At $200 \mathrm{nM} \mathrm{V}_{\mathrm{H}} \mathrm{H}$ concentrations, all of our $\mathrm{V}_{\mathrm{H}} \mathrm{Hs}$ bound the QCD-32g58 LMW subunit (Fig. 2b; Table 2). A similar affinity rank pattern to the full SLP was observed: SLP_V $\mathrm{H}_{\mathrm{H}} \mathrm{H}$, SLP_V $\mathrm{V}_{\mathrm{H}} \mathrm{H} 12, \mathrm{SLP}_{-} \mathrm{V}_{\mathrm{H}} \mathrm{H} 23$, and SLP_ $\mathrm{V}_{\mathrm{H}} \mathrm{H} 46$ had the lowest $K_{\mathrm{D}} \mathrm{S}$ of all $\mathrm{V}_{\mathrm{H}} \mathrm{Hs}$ tested, SLP_ $\mathrm{V}_{\mathrm{H}} \mathrm{H} 2$ and SLP_ $\mathrm{V}_{\mathrm{H}} \mathrm{H} 26$ had the highest $K_{\mathrm{D}} \mathrm{S}$, and the remaining $\mathrm{V}_{\mathrm{H}} \mathrm{Hs}$ had intermediate $K_{\mathrm{D}} \mathrm{s}$. Interestingly, the $\mathrm{V}_{\mathrm{H}} \mathrm{Hs}$ bound with higher affinities to the LMW SLP than the full SLP, suggesting a more optimal epitope presentation on the SPR chip for the LMW SLP. Collectively, the SPR binding data indicated the epitopes recognized by anti-SLP $\mathrm{V}_{\mathrm{H}} \mathrm{Hs}$ reside entirely in the LMW subunit of QCD-32g58 SLP, and that some level of cross-reactivity to 630 SLP, presumably with the LMW subunit, was evident for a subset of the $\mathrm{V}_{\mathrm{H}} \mathrm{Hs}$. These findings are consistent with earlier reports that showed the LMW SLP subunit is immunodominant (Spigaglia et al. 2011) and that cross-reactive antibodies to the LMW SLP subunit from different $C$. difficile ribotypes are rare due to the low amino acid sequence homology (Calabi et al. 2001). To determine if the QCD-32g58 SLP epitope recognized by the $\mathrm{V}_{\mathrm{H}} \mathrm{Hs}$ was linear or conformational, a denaturing SDS-PAGE-Western blot was performed. QCD32g58 SLPs were separated in an SDS-PAGE gel under reducing conditions, transferred to a PVDF membrane, and probed with individual $\mathrm{V}_{\mathrm{H}} \mathrm{Hs}$ followed by detection with an anti-His ${ }_{6}$ IgG conjugated to alkaline phosphatase (Fig. 2c). A nontransferred SDS-PAGE was run to demonstrate the presence of both HMW and LMW QCD-32g58 SLP subunits in the samples (Fig. 2c, left panel). Moreover, a Western blot performed against transferred $\mathrm{V}_{\mathrm{H}} \mathrm{Hs}$ confirmed all $\mathrm{V}_{\mathrm{H}} \mathrm{Hs}$ had their $\mathrm{His}_{6}$ tag. The $\mathrm{V}_{\mathrm{H}} \mathrm{Hs}$ SLP_ $\mathrm{V}_{\mathrm{H}} \mathrm{H} 5$, SLP_ $\mathrm{V}_{\mathrm{H}} \mathrm{H} 12$, SLP_V ${ }_{\mathrm{H}} \mathrm{H} 23$, SLP_V $\mathrm{V}_{\mathrm{H}} \mathrm{H} 46$, and SLP_V $\mathrm{V}_{\mathrm{H}} \mathrm{H} 49$ bound the LMW subunit of QCD-32g58 SLP, consistent with our SPR results (Fig. 2b), and indicating that these $\mathrm{V}_{\mathrm{H}} \mathrm{Hs}$ recognized a linear epitope. The remaining $\mathrm{V}_{\mathrm{H}} \mathrm{Hs}$ were weakly positive, or negative altogether, by Western blot for binding to the LMW subunit of QCD-32g58 SLP, indicating that they may recognize conformational epitopes, or have too low of an affinity and/or $k_{\mathrm{off}} \mathrm{s}$ too rapid to produce a detectible signal.

\section{Binding of $\mathrm{V}_{\mathrm{H}} \mathrm{Hs}$ to $C$. difficile cells}

ELISA was used to determine the ability of each $\mathrm{V}_{\mathrm{H}} \mathrm{H}$ to bind to a number of $C$. difficile clinical isolates. All SLP-specific $\mathrm{V}_{\mathrm{H}} \mathrm{Hs}$ in this study bound bacterial cells of strain QCD-32g58 (Fig. 3a). In addition, strong reactivity of each $\mathrm{V}_{\mathrm{H}} \mathrm{H}$ to the bacterial cell surface of a number of other $C$. difficile isolates which belong to the same 027 hypervirulent ribotype (BI-1, BI-7, 196, R20291) as well as ribotype 001 (strain 001_01) was observed. In contrast, $\mathrm{V}_{\mathrm{H}} \mathrm{H}$ reactivity to the cell surface of representative strains from other ribotypes $(012,017,023$, and 

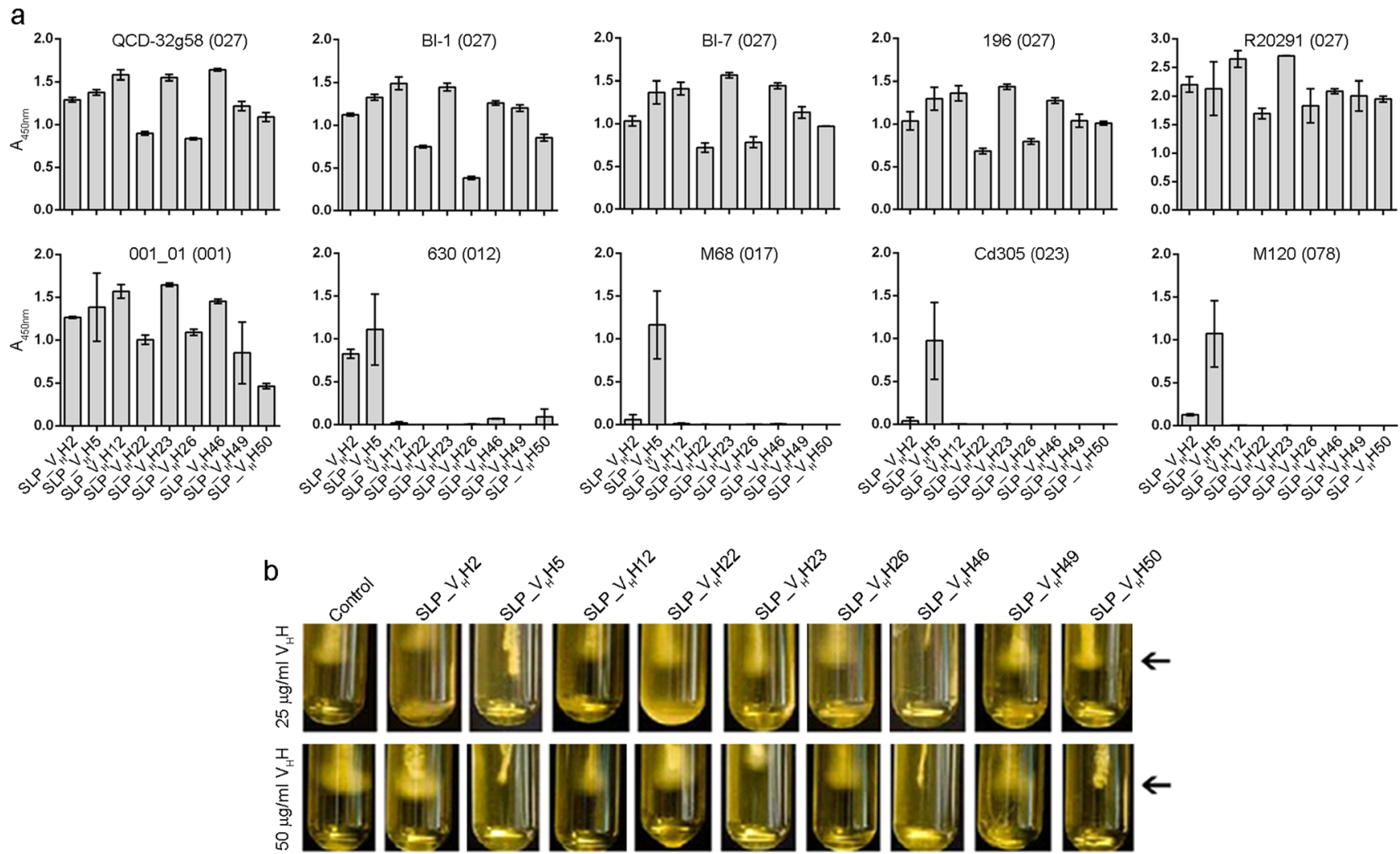

Fig. 3 SLP-specific $\mathrm{V}_{\mathrm{H}} \mathrm{Hs}$ bind $C$. difficile cells and inhibit motility. a Whole cell ELISA demonstrating the binding of $\mathrm{V}_{\mathrm{H}} \mathrm{Hs}$ to various C. difficile strains. b $C$. difficile (QCD-32g58) stabs after $23 \mathrm{~h}$ comparing the effects of 25 and $50 \mu \mathrm{g} / \mathrm{ml} \mathrm{V} \mathrm{V}_{\mathrm{H}} \mathrm{H}$ concentrations on

078) was far more restricted, suggesting considerable diversity in the LMW SLP epitopes displayed among distinct lineages of $C$. difficile. Interestingly, $\mathrm{SLP}_{-} \mathrm{V}_{\mathrm{H}} \mathrm{H} 5$ was able to recognize all $C$. difficile isolates tested, representing a number of distinct ribotypes. While both $\mathrm{SLP}_{-} \mathrm{V}_{\mathrm{H}} \mathrm{H} 2$ and $\mathrm{SLP}_{-} \mathrm{V}_{\mathrm{H}} \mathrm{H} 26$ were shown to cross-react to 630 SLP in phage ELISA and SPR assays, it was only SLP_ $\mathrm{V}_{\mathrm{H}} \mathrm{H} 2$ that cross-reacted to 630 SLP in cell binding assays.

\section{C. difficile motility assays}

Despite a lack of evidence in the literature relating SLP function to bacterial motility, we nonetheless sought to test the ability of SLP-specific $\mathrm{V}_{\mathrm{H}} \mathrm{Hs}$ to inhibit $C$. difficile (QCD$32 \mathrm{~g} 58$ strain) motility. Culture tubes containing BHI-agar supplemented with $\mathrm{V}_{\mathrm{H}} \mathrm{Hs}$ at either $25 \mu \mathrm{g} / \mathrm{ml}(\sim 1.5 \mu \mathrm{M})$ or $50 \mu \mathrm{g} / \mathrm{ml}(\sim 3 \mu \mathrm{M})$ were inoculated with stabs of $C$. difficile and cultured for $23 \mathrm{~h}$. Growth was monitored and photographed $23 \mathrm{~h}$ postinoculation (Fig. 3b). Motile cells displayed a diffuse spreading flare of growth at the bottom of the inoculating stab. The results demonstrated that at $23 \mathrm{~h}$ postinoculation using $25-\mu \mathrm{g} / \mathrm{ml}$ antibody concentrations, SLP $\mathrm{V}_{\mathrm{H}} \mathrm{H} 5$ and SLP $\mathrm{V}_{\mathrm{H}} \mathrm{H} 46$ completely inhibited C. difficile motility. SLP $\mathrm{V}_{\mathrm{H}} \mathrm{H} 50$ showed slight inhibition of bacterial motility. SLP_V $\mathrm{H}_{\mathrm{H}} \mathrm{H}$, SLP_ $\mathrm{V}_{\mathrm{H}} \mathrm{H} 46$, and SLP_V $\mathrm{V}_{\mathrm{H}} \mathrm{H} 50$ showed inhibition of $C$. difficile motility, denoted with arrows at the tip of the stabs

motility at $25 \mu \mathrm{g} / \mathrm{ml}$. The remaining $\mathrm{V}_{\mathrm{H}} \mathrm{Hs}$ did not inhibit motility at concentrations of $25 \mu \mathrm{g} / \mathrm{ml}$. To test whether motility inhibition was concentration dependent, we doubled the antibody concentration to $50 \mu \mathrm{g} / \mathrm{ml}$ (Fig. 3b). Similar to the lower concentration, SLP_ $\mathrm{V}_{\mathrm{H}} \mathrm{H} 5$ and SLP_ $\mathrm{V}_{\mathrm{H}} \mathrm{H} 46$ clearly inhibited $C$. difficile motility. Increasing the concentration of SLP_ $V_{\mathrm{H}} \mathrm{H} 50$ to $50 \mu \mathrm{g} / \mathrm{ml}$ resulted in complete inhibition of C. difficile motility.

\section{Discussion}

The outer surface of many bacteria is covered in a proteinaceous coat called the S-layer (surface layer) that is involved in growth, function, and interaction with the host (Fagan and Fairweather 2014). In Gram-positive species, such as C. difficile, SLPs have been shown to play a role in adherence to gastrointestinal tract cells and extracellular matrix components (Calabi et al. 2002; Takumi et al. 1991), and recently, SLPs were shown to have a role in activating innate and adaptive immunity through TLR4 (Ryan et al. 2011) and induce pro-inflammatory cytokines (Bianco et al. 2011; Collins et al. 2014). It has been known for several years that patients with recurrent episodes of $C$. difficile have significantly lower anti- 
SLP IgM titers than patients experiencing a single episode of C. difficile infection (Drudy et al. 2004). In addition, active immunization of hamsters with SLPs elucidated partial protection when challenged with $C$. difficile (Ni Eidhin et al. 2008). Collectively, this suggests that SLPs may have a critical role in $C$. difficile pathogenesis and virulence in humans, making them targets for diagnostic probes, vaccine development and novel therapeutic agents. In $C$. difficile, mature SLPs consist of HMW and LMW subunits which are produced by proteolytic cleavage of a single polypeptide chain (SIpA). In a mature SLP, the LMW subunit is displayed toward the environment and shows higher sequence variability than the HMW subunit (Calabi and Fairweather 2002; Merrigan et al. 2013).

To explore the use of antibodies targeting novel $C$. difficile virulence factors, we produced high-affinity llama $\mathrm{V}_{\mathrm{H}} \mathrm{Hs}$ to C. difficile SLPs. We isolated SLPs from the hypervirulent QCD-32g58 strain (027 ribotype) and the 630 reference strain (012 ribotype), immunized a llama with both simultaneously, isolated several $\mathrm{V}_{\mathrm{H}} \mathrm{Hs}$, and characterized these antibodies. Immunization with SLPs generated a strong heavy-chain antibody immune response in the llama, indicating the SLPs were very immunogenic. From a phage display library panned with SLPs from QCD-32g58, nine unique $\mathrm{V}_{\mathrm{H}} \mathrm{Hs}$ were isolated. By phage ELISA and SPR, all recognized QCD-32g58 SLP, while two (SLP_ $\mathrm{V}_{\mathrm{H}} \mathrm{H} 2$ and SLP_ $\left.\mathrm{V}_{\mathrm{H}} \mathrm{H} 26\right)$ cross-reacted to $630 \mathrm{SLP}$, with at least more than half of the $\mathrm{V}_{\mathrm{H}} \mathrm{Hs}$ recognizing linear epitopes. SPR binding of $\mathrm{V}_{\mathrm{H}} \mathrm{Hs}$ revealed highaffinity binding to QCD-32g58 SLP with $K_{\mathrm{D}} \mathrm{s}$ as low as 3$6 \mathrm{nM}$, but nonetheless, several $\mathrm{V}_{\mathrm{H}} \mathrm{Hs}$ also had significantly higher $K_{\mathrm{D}}$ s, as high as $580 \mathrm{nM}$, a $K_{\mathrm{D}}$ range pattern frequently seen with $\mathrm{V}_{\mathrm{H}} \mathrm{Hs}$ obtained from immune $\mathrm{V}_{\mathrm{H}} \mathrm{H}$ phage display libraries. Interestingly, the four $\mathrm{V}_{\mathrm{H}} \mathrm{Hs}$ with the highest affinities (3-6 nM) all recognize linear epitopes. Despite immunizing and panning with the QCD-32g58 whole SLP, all of the $\mathrm{V}_{\mathrm{H}} \mathrm{Hs}$ targeted the highly variable LMW subunit. The HMW subunit is conserved across $C$. difficile isolates and the LMW subunit is considerably more variable (Calabi and Fairweather 2002; Merrigan et al. 2013). In agreement with our findings, between the LMW and HMW subunits, the LMW one has been shown to be the immunodominant antigen elsewhere (Ausiello et al. 2006; Péchiné et al. 2007).

With respect to thermostability, $\mathrm{V}_{\mathrm{H}} \mathrm{Hs}$ showed $T_{\mathrm{m}} \mathrm{s}$ as high as $75{ }^{\circ} \mathrm{C}$, although engineered $\mathrm{V}_{\mathrm{H}} \mathrm{Hs}$ with higher $T_{\mathrm{m}} \mathrm{s}$ have been previously reported, in the range of $79-94{ }^{\circ} \mathrm{C}$ (Hussack et al. 2011b; Zabetakis et al. 2014). $\mathrm{V}_{\mathrm{H}} \mathrm{Hs}$ also showed significant resistance to the GI enzyme pepsin with two $\mathrm{V}_{\mathrm{H}} \mathrm{Hs}$ having pepsin resistance as high as $20 \%$ at a physiologically relevant pepsin concentration $(100 \mu \mathrm{g} / \mathrm{ml})$. Noticeably, three out of the four $\mathrm{V}_{\mathrm{H}} \mathrm{Hs}$ that showed pepsin resistance at a relatively high enzyme concentration $(50 \mu \mathrm{g} / \mathrm{ml})$ have the highest $T_{\mathrm{m}} \mathrm{s}\left(73.7-75.4^{\circ} \mathrm{C}\right)$, and SLP $\mathrm{V}_{\mathrm{H}} \mathrm{H} 22$, which was the most resistant $\mathrm{V}_{\mathrm{H}} \mathrm{H}$, had a pair of Cys at positions 55 and in CDR3 that formed an extra disulfide linkage. Previously, a positive correlation was found between pepsin resistance and $T_{\mathrm{m}}$, and mutations that increased $T_{\mathrm{m}}$ also increased pepsin resistance (Hussack et al. 2011b). The extra noncanonical disulfide linkage in SLP $\mathrm{V}_{\mathrm{H}} \mathrm{H} 22$ may be a contributor to its high $T_{\mathrm{m}}$ and/or pepsin resistance. Previously, similar noncanonical (interCDR1-CDR3; inter-CDR2-CDR3) disulfide linkages were shown to increase the stability of $\mathrm{V}_{\mathrm{H}} \mathrm{Hs}$ (Govaert et al. 2012; Zabetakis et al. 2014). In particular, a disulfide linkage formed between a pair of Cys residues at positions 55 and in CDR3 improved the $T_{\mathrm{m}}$ of a $\mathrm{V}_{\mathrm{H}} \mathrm{H}$ by several degrees (Zabetakis et al. 2014). However, we find that in addition to forming the expected noncanonical disulfide linkage between them, Cys55 and CDR3 Cys also pair up with Cys23 or Cys104 - which are involved in a highly conserved canonical disulfide linkage in $\mathrm{V}_{\mathrm{H}} \mathrm{Hs}$ - to form unusual disulfide linkages not reported previously. Whether these unusual disulfide linkages are the result of heterologous expression in E. coli is not clear to us. It is also unclear if they are present in significant proportions of the $\mathrm{V}_{\mathrm{H}} \mathrm{H}$ population.

We tested the ability of $\mathrm{V}_{\mathrm{H}} \mathrm{Hs}$ to bind $C$. difficile whole cells in ELISA, which presents the SLP protein in a more natural context for antibody binding. All nine $\mathrm{V}_{\mathrm{H}} \mathrm{Hs}$ bound QCD-32g58 cells and, not surprisingly, all other 027 ribotype strains tested, including BI-1, BI-7, 196, and R20291, which have identical LMW subunit SLP sequences to QCD-32g58. These results confirm the feasibility of using purified, out-ofnatural-context SLP as an immunogen and target antigen for panning experiments for obtaining anti-SLP antibodies that recognize parent cells equally well. As well, the panel of $\mathrm{V}_{\mathrm{H}} \mathrm{Hs}$ all bound to a 001 ribotype strain, indicating that at least the LMW subunit of 001 ribotype strain should have high sequence identity to the SLP LMW subunits from the aforementioned 027 ribotypes. SLP_ $\mathrm{V}_{\mathrm{H}} \mathrm{H} 2$ showed binding to 630 , which was expected given the evidence of crossreactivity in ELISA and SPR. SLP_ $\mathrm{V}_{\mathrm{H}} \mathrm{H} 26$ did not show binding to 630 cells, despite earlier ELISA and SPR evidence showing binding to $630 \mathrm{SLPs}$. Interestingly, SLP_ $\mathrm{V}_{\mathrm{H}} \mathrm{H} 5$ bound all ribotypes tested in the cell ELISA format, indicating the antibody is broadly cross-reactive. Why SLP_ $\mathrm{V}_{\mathrm{H}} \mathrm{H} 5$ failed to recognize 630 SLPs in phage ELISA and SPR is not entirely clear, but it could be due to the fact that immobilizing the SLP prevented antibody binding by masking or changing the conformation of the epitope. Differential epitope presentations may also account for binding inconsistencies observed for SLP_ $\mathrm{V}_{\mathrm{H}} \mathrm{H} 26$ between phage ELISA/SPR assays and cell ELISA assay. The remaining $\mathrm{V}_{\mathrm{H}} \mathrm{Hs}$ did not bind cells representative of $012,017,023$ or 078 ribotypes. The low frequency of cross-reactive $\mathrm{V}_{\mathrm{H}} \mathrm{Hs}$ may not be surprising given the low amino acid identity among SLP LMW subunits from different ribotypes. We speculate that at least six different epitopes are being recognized by our pool of $\mathrm{V}_{\mathrm{H}} \mathrm{Hs}$, given that there are five different specificities inferred from cell binding, motility 
and ELISA/SPR assays, one represented by SLP $\mathrm{V}_{\mathrm{H}} \mathrm{H} 2$, one by SLP $\mathrm{V}_{\mathrm{H}} \mathrm{H} 5$, one by SLP $\mathrm{V}_{\mathrm{H}} \mathrm{H} 26$ that cross-reacted to 630 strain in phage ELISA/SPR, one by SLP $\mathrm{V}_{\mathrm{H}} \mathrm{H} 46$ and SLP_ $\mathrm{V}_{\mathrm{H}} \mathrm{H} 50$ that inhibited motility, and one represented by the remaining $\mathrm{V}_{\mathrm{H}} \mathrm{Hs}\left(\mathrm{SLP}_{-} \mathrm{V}_{\mathrm{H}} \mathrm{H} 12, \mathrm{SLP}_{-} \mathrm{V}_{\mathrm{H}} \mathrm{H} 22\right.$, $\mathrm{SLP}_{-} \mathrm{V}_{\mathrm{H}} \mathrm{H} 23$, and $\mathrm{SLP}_{-} \mathrm{V}_{\mathrm{H}} \mathrm{H} 49$ ). This latter group can be divided into those binding a linear epitope and those binding a conformational epitope as determined by Western blotting.

Despite their variability, alignment of LMW SLP amino acid sequences from several $C$. difficile ribotypes reveal stretches of conserved residues that could represent epitopes for cross-reactive antibody binding (Fig. S4). Specifically, residues 8-11, 72-83, 249-261, 264-275, and 299-321, numbered based on the 630 sequence, show significant homology across all aligned ribotypes (Fagan et al. 2009). Based on LMW SLP structural data, the LMW SLP is composed of domain 1 (residues 1-87 and residues 242-248) and domain 2 (residues 97-233), with domain 1 facing toward the bacterial cell wall and the HMW subunit, while domain 2 is orientated away, toward the environment (Fagan et al. 2009). The residues of domain 2 show the most variability among ribotypes (Fig. S4) and are also likely the most accessible for antibody binding given they extend away from the bacterial surface. In the case of the broadly cross-reactive SLP_ $\mathrm{V}_{\mathrm{H}} \mathrm{H} 5$ antibody, it is possible that even though domain 1 of the LMW SLP faces inward toward the cell wall and is in close proximity to the HMW SLP interaction domain, domain 1 residues remain accessible for binding. Further studies on this antibody, including co-crystallization structure determination, could reveal the true nature of the LMW epitope.

Somewhat surprisingly, in agar-stab motility assays, several $\mathrm{V}_{\mathrm{H}} \mathrm{Hs}$ were capable of inhibiting motility of QCD-32g58 cells. In particular, SLP $\mathrm{V}_{\mathrm{H}} \mathrm{H} 5$ and $\mathrm{SLP}_{-} \mathrm{V}_{\mathrm{H}} \mathrm{H} 46$ were capable of inhibiting motility at both high and low antibody concentrations. To a lesser degree, SLP $\mathrm{V}_{\mathrm{H}} \mathrm{H} 50$ was also found to inhibit motility. Higher affinity, faster $k_{\text {on }}$ /slower $k_{\text {off }}$ and/or the nature of epitope of SLP $\mathrm{V}_{\mathrm{H}} \mathrm{H} 5$ and SLP $\mathrm{V}_{\mathrm{H}} \mathrm{H} 46$ may be responsible for their greater motility inhibition potency compared to SLP $\mathrm{V}_{\mathrm{H}} \mathrm{H} 50$ (based on Western blot and cellbinding experiments, SLP $\mathrm{V}_{\mathrm{H}} \mathrm{H} 5$ and $\mathrm{SLP}_{-} \mathrm{V}_{\mathrm{H}} \mathrm{H} 46$ have different epitopes than $\mathrm{SLP}_{-} \mathrm{V}_{\mathrm{H}} \mathrm{H} 50$ ). There are a limited number of reports of polyclonal antibody and $\mathrm{mAb}$ preparations targeting $C$. difficile SLPs; however, none have examined the ability of antibodies to inhibit $C$. difficile motility. Takumi et al. (1991) produced anti-SLP Fab fragments and used them to inhibit the adherence of $C$. difficile to human cervical cancer cells and mouse fibroblast cells. O'Brien et al. (2005) showed that the injection of hamsters with antibodies to SLPs prolonged the survival of $C$. difficile-infected hamsters. More recently, anti-HMW SlpA and anti-LMW SlpA polyclonal antiserum was shown to reduce $C$. difficile strain 630 adherence to $C 2_{\mathrm{BBE}}$ human colonic epithelial cells although the precise mechanism was not defined (Merrigan et al. 2013). While our study is unique in that we appear to inhibit motility through targeting $C$. difficile SLPs, others have found motility-inhibiting affinity reagents by targeting an alternative bacterial cell surface structure, namely the lipopolysaccharide (LPS). A mAb that bound the LPS of Salmonella enterica was shown to inhibit flagellum-based motility (Forbes et al. 2008). Similarly, P22sTsp, a phage tailspike protein that binds to LPS was also able to inhibit the motility of Salmonella enterica serovar Typhimurium (Waseh et al. 2010). As would be expected an anti-flagellin mAb inhibited the motility of multi-drug resistant Pseudomonas aeruginosa and curbed lethality in mice (Adawi et al. 2012). In another study, anti- $P$. aeruginos $a$ flagellin $\mathrm{V}_{\mathrm{H}} \mathrm{Hs}$ inhibited the motility and biofilm formation of $P$. aeruginosa (Adams et al. 2014). Similarly an anti-Campylobacter jejuni flagellin $\mathrm{V}_{\mathrm{H}} \mathrm{H}$ inhibited the motility of $C$. jejuni (Hussack et al. 2014; Riazi et al. 2013). To date, there is no known report of SLP interactions with motility factors in $C$. difficile and SLPs remain the primary adherence factors of $C$. difficile. However, the theme of blocking a surface antigen which is high in abundance, wherein motility is reduced, is presented in this study and warrants further investigation. Our data suggests that antibodies binding to $C$. difficile SLPs may provide some form of steric hindrance to the effective functioning of the flagellar motility apparatus. Continued studies on the structure and function of $C$. difficile SLPs and their role in host-pathogen interactions, as well as nature of the LMW epitope recognized by broadly cross-reactive SLP antibodies which inhibit motility, will help in elucidating this unusual interaction between two key surface structures. Whether our SLP-specific $\mathrm{V}_{\mathrm{H}} \mathrm{Hs}$ interfere with cell growth and biofilm formation warrants further investigation.

In conclusion, we have isolated a panel of high-affinity $\mathrm{V}_{\mathrm{H}} \mathrm{Hs}$ that target the LMW SLP subunit of $C$. difficile QCD32g58. Many of the $\mathrm{V}_{\mathrm{H}} \mathrm{Hs}$ recognized several strains within the 027 ribotype, which is the predominant hypervirulent ribotype seen in hospital-acquired (nosocomial) $C$. difficile infections. One $\mathrm{V}_{\mathrm{H}} \mathrm{H}\left(\mathrm{SLP} \mathrm{V}_{\mathrm{H}} \mathrm{H} 5\right)$ additionally recognized two strains from ribotypes 017 and 078 which are recognized as emerging PCR ribotypes implicated in recent outbreaks with increased disease severity (Cheknis et al. 2009; Hunt and Ballard 2013). Of additional significance, a subset of four $\mathrm{V}_{\mathrm{H}} \mathrm{Hs}\left(\mathrm{SLP} \mathrm{V}_{\mathrm{H}} \mathrm{H} 5, \mathrm{SLP}_{-} \mathrm{V}_{\mathrm{H}} \mathrm{H} 12\right.$, SLP $\mathrm{V}_{\mathrm{H}} \mathrm{H} 23$, and SLP_ $\left.\mathrm{V}_{\mathrm{H}} \mathrm{H} 46\right)$ possessed high affinities, a similar set (SLP_ $\mathrm{V}_{\mathrm{H}} \mathrm{H} 5, \mathrm{SLP}_{-} \mathrm{V}_{\mathrm{H}} \mathrm{H} 46$, and SLP $\left.\mathrm{V}_{\mathrm{H}} \mathrm{H} 50\right)$ inhibited motility and two (SLP $\mathrm{V}_{\mathrm{H}} \mathrm{H} 12$ and $\left.\mathrm{SLP}_{-} \mathrm{V}_{\mathrm{H}} \mathrm{H} 23\right)$ demonstrated strong resistance to the GI protease pepsin. Affinity maturation combined with a disulfide engineering approach described previously (Hussack et al. 2011b; Hussack et al. 2014; Saerens et al. 2008) can be employed to further increase their affinities, motility inhibition capability and resistance to GI proteases, making them suitable oral/GI therapeutics against CDAD or useful agents in the validation of SLP as a 
vaccine target. A combination therapy approach involving the present anti-SLP $\mathrm{V}_{\mathrm{H}} \mathrm{Hs}$ and previously described toxin A- and toxin B-specific $\mathrm{V}_{\mathrm{H}} \mathrm{Hs}$ (Hussack et al. 2011a; Yang et al. 2014) also appears attractive.

Acknowledgments We thank W. Ding and J. F. Kelly (National Research Council Canada, Ottawa, ON, Canada) for performing mass spectrometry analysis, A. Dascal (Jewish General Hospital, Montreal, QC, Canada) for providing strain QCD-32g58, and B. Wren (LSHTM, London, UK) for providing strains 630, R20291, BI-1, BI-7, 196, 001_01, M68, Cd305, and M120.

Conflict of interest The authors declare that they have no conflict of interest.

Ethical statement All procedures involving llamas and their care in this study were approved by the Animal Care Committee of Cedarlane licensed by the Ontario Ministry of Agriculture, Food and Rural Affairs.

Open Access This article is distributed under the terms of the Creative Commons Attribution 4.0 International License (http:// creativecommons.org/licenses/by/4.0/), which permits unrestricted use, distribution, and reproduction in any medium, provided you give appropriate credit to the original author(s) and the source, provide a link to the Creative Commons license, and indicate if changes were made.

\section{References}

Adams H, Horrevoets WM, Adema SM, Carr HE, van Woerden RE, Koster M, Tommassen J (2014) Inhibition of biofilm formation by camelid single-domain antibodies against the flagellum of Pseudomonas aeruginosa. J Biotechnol 186:66-73

Adawi A, Bisignano C, Genovese T, Filocamo A, Khouri-Assi C, Neville A, Feuerstein GZ, Cuzzocrea S, Neville LF (2012) In vitro and in vivo properties of a fully human IgG1 monoclonal antibody that combats multidrug resistant Pseudomonas aeruginosa. Int J Mol Med 30:455-464

Åkerlund T, Persson I, Unemo M, Norén T, Svenungsson B, Wullt M, Burman LG (2008) Increased sporulation rate of epidemic Clostridium difficile Type 027/NAP1. J Clin Microbiol 46:1530 1533

Ausiello CM, Cerquetti M, Fedele G, Spensieri F, Palazzo R, Nasso M, Frezza S, Mastrantonio P (2006) Surface layer proteins from Clostridium difficile induce inflammatory and regulatory cytokines in human monocytes and dendritic cells. Microbes Infect 8:2640 2646

Bianco M, Fedele G, Quattrini A, Spigaglia P, Barbanti F, Mastrantonio P, Ausiello CM (2011) Immunomodulatory activities of surface-layer proteins obtained from epidemic and hypervirulent Clostridium difficile strains. J Med Microbiol 60:1162-1167

Bourgault AM, Lamothe F, Loo VG, Poirier L (2006) In vitro susceptibility of Clostridium difficile clinical isolates from a multiinstitutional outbreak in Southern Québec, Canada. Antimicrob Agents Chemother 50:3473-3475

Calabi E, Fairweather N (2002) Patterns of sequence conservation in the $\mathrm{S}$-layer proteins and related sequences in Clostridium difficile. $\mathrm{J}$ Bacteriol 184:3886-3897

Calabi E, Ward S, Wren B, Paxton T, Panico M, Morris H, Dell A, Dougan G, Fairweather N (2001) Molecular characterization of the surface layer proteins from Clostridium difficile. Mol Microbiol 40: $1187-1199$
Calabi E, Calabi F, Phillips AD, Fairweather NF (2002) Binding of Clostridium difficile surface layer proteins to gastrointestinal tissues. Infec Immun 70:5770-5778

Cegelski L, Marshall GR, Eldridge GR, Hultgren SJ (2008) The biology and future prospects of antivirulence therapies. Nat Rev Microbiol 6: $17-27$

Cheknis AK, Sambol SP, Davidson DM, Nagaro KJ, Mancini MC, Hidalgo-Arroyo GA, Brazier JS, Johnson S, Gerding DN (2009) Distribution of Clostridium difficile strains from a North American, European and Australian trial of treatment for C. difficile infections: 2005-2007. Anaerobe 15:230-233

Clatworthy AE, Pierson E, Hung DT (2007) Targeting virulence: a new paradigm for antimicrobial therapy. Nat Chem Biol 3:541-548

Collins LE, Lynch M, Marszalowska I, Kristek M, Rochfort K, O'Connell M, Windle H, Kelleher D, Loscher CE (2014) Surface layer proteins isolated from Clostridium difficile induce clearance responses in macrophages. Microbes Infect 16:391-400

Drudy D, O'Donoghue DP, Baird A, Fenelon L, O'Farrelly C (2001) Flow cytometric analysis of Clostridium difficile adherence to human intestinal epithelial cells. J Med Microbiol 50:526-534

Drudy D, Calabi E, Kyne L, Sougioultzis S, Kelly E, Fairweather N, Kelly CP (2004) Human antibody response to surface layer proteins in Clostridium difficile infection. FEMS Immunol Med Microbiol 41:237-242

Dubberke ER, Olsen MA (2012) Burden of Clostridium difficile on the healthcare system. Clin Infect Dis 55(Suppl 2):S88-S92

Dubreuil JD, Logan SM, Cubbage S, Eidhin DN, McCubbin WD, Kay CM, Beveridge TJ, Ferris FG, Trust TJ (1988) Structural and biochemical analyses of a surface array protein of Campylobacter fetus. J Bacteriol 170:4165-4173

Dupuy B, Govind R, Antunes A, Matamouros S (2008) Clostridium difficile toxin synthesis is negatively regulated by TcdC. J Med Microbiol 57:685-689

Fagan RP, Fairweather NF (2014) Biogenesis and functions of bacterial S-layers. Nat Rev Microbiol 12:211-222

Fagan RP, Albesa-Jove D, Qazi O, Svergun DI, Brown KA, Fairweather NF (2009) Structural insights into the molecular organization of the S-layer from Clostridium difficile. Mol Microbiol 71:1308-1322

Forbes SJ, Eschmann M, Mantis NJ (2008) Inhibition of Salmonella enterica serovar Typhimurium motility and entry into epithelial cells by a protective antilipopolysaccharide monoclonal immunoglobulin A antibody. Infect Immun 76:4137-4144

Forgetta V, Oughton MT, Marquis P, Brukner I, Blanchette R, Haub K, Magrini V, Mardis ER, Gerding DN, Loo VG, Miller MA, Mulvey MR, Rupnik M, Dascal A, Dewar K (2011) Fourteen-genome comparison identifies DNA markers for severe-disease-associated strains of Clostridium difficile. J Clin Microbiol 49:2230-2238

Ghantoji SS, Sail K, Lairson DR, DuPont HL, Garey KW (2010) Economic healthcare costs of Clostridium difficile infection: a systematic review. J Hosp Infect 74:309-318

Ghose C (2013) Clostridium difficile infection in the twenty-first century. Emerg Microbes Infect 2:e62

Giannasca PJ, Warny M (2004) Active and passive immunization against Clostridium difficile diarrhea and colitis. Vaccine 22:848-856

Gilca R, Hubert B, Fortin E, Gaulin C, Dionne M (2010) Epidemiological patterns and hospital characteristics associated with increased incidence of Clostridium difficile infection in Québec, Canada, 19982006. Infect Control Hosp Epidemiol 31:939-947

Govaert J, Pellis M, Deschacht N, Vincke C, Conrath K, Muyldermans S, Saerens D (2012) Dual beneficial effect of interloop disulfide bond for single domain antibody fragments. J Biol Chem 287:1970-1979

Grogono-Thomas R, Dworkin J, Blaser MJ, Newell DG (2000) Roles of the surface layer proteins of Campylobacter fetus subsp. fetus in ovine abortion. Infect Immun 68:1687-1691

Hamadeh RM, Estabrook MM, Zhou P, Jarvis GA, Griffiss JM (1995) Anti-Gal binds to pili of Neisseria meningitidis: the 
immunoglobulin A isotype blocks complement-mediated killing. Infect Immun 63:4900-4906

Harmsen MM, De Haard HJ (2007) Properties, production, and applications of camelid single-domain antibody fragments. Appl Microbiol Biotechnol 77:13-22

Harmsen MM, Ruuls RC, Nijman IJ, Niewold TA, Frenken LG, de Geus B (2000) Llama heavy-chain V regions consist of at least four distinct subfamilies revealing novel sequence features. Mol Immunol 37:579-590

Harmsen MM, van Solt CB, Fijten HP, van Keulen L, Rosalia RA, Weerdmeester K, Cornelissen AH, De Bruin MG, Eble PL, Dekker A (2007) Passive immunization of guinea pigs with llama single-domain antibody fragments against foot-and-mouth disease. Vet Microbiol 120:193-206

Holliger P, Hudson PJ (2005) Engineered antibody fragments and the rise of single domains. Nat Biotechnol 23:1126-1136

Holt LJ, Herring C, Jespers LS, Woolven BP, Tomlinson IM (2003) Domain antibodies: proteins for therapy. Trends Biotechnol 21: 484-490

Hubert B, Loo VG, Bourgault AM, Poirier L, Dascal A, Fortin E, Dionne M, Lorange M (2007) A portrait of the geographic dissemination of the Clostridium difficile North American pulsed-field type 1 strain and the epidemiology of $C$. difficile-associated disease in Québec. Clin Infect Dis 44:238-244

Hunt JJ, Ballard JD (2013) Variations in virulence and molecular biology among emerging strains of Clostridium difficile. Microbiol Mol Biol Rev 77:567-581

Hussack G, Tanha J (2010) Toxin-specific antibodies for the treatment of Clostridium difficile: current status and future perspectives. Toxins 2:998-1018

Hussack G, Arbabi-Ghahroudi M, van Faassen H, Songer JG, Ng KK, MacKenzie R, Tanha J (2011a) Neutralization of Clostridium difficile toxin A with single-domain antibodies targeting the cell receptor binding domain. J Biol Chem 286:8961-8976

Hussack G, Hirama T, Ding W, Mackenzie R, Tanha J (2011b) Engineered single-domain antibodies with high protease resistance and thermal stability. PLoS One 6:e28218

Hussack G, Arbabi-Ghahroudi M, Mackenzie CR, Tanha J (2012) Isolation and characterization of Clostridium difficile toxin-specific single-domain antibodies. Methods Mol Biol 911:211-239

Hussack G, Riazi A, Ryan S, van Faassen H, MacKenzie R, Tanha J, Arbabi-Ghahroudi M (2014) Protease-resistant single-domain antibodies inhibit Campylobacter jejuni motility. Protein Eng Des Sel 27:191-198

Jank T, Aktories K (2008) Structure and mode of action of clostridial glucosylating toxins: the ABCD model. Trends Microbiol 16:222 229

Jank T, Giesemann T, Aktories K (2007) Rho-glucosylating Clostridium difficile toxins $\mathrm{A}$ and $\mathrm{B}$ : new insights into structure and function. Glycobiology 17:15R-22R

Janvilisri T, Scaria J, Thompson AD, Nicholson A, Limbago BM, Arroyo LG, Songer JG, Gröhn YT, Chang YF (2009) Microarray identification of Clostridium difficile core components and divergent regions associated with host origin. J Bacteriol 191:3881-3891

Karas JA, Enoch DA, Aliyu SH (2010) A review of mortality due to Clostridium difficile infection. J Infect 61:1-8

Kim DY, Ding W, Tanha J (2012a) Solubility and stability engineering of human $\mathrm{V}_{\mathrm{H}}$ domains. Methods Mol Biol 911:355-372

Kim DY, Kandalaft H, Ding W, Ryan S, van Faassen H, Hirama T, Foote SJ, MacKenzie R, Tanha J (2012b) Disulfide linkage engineering for improving biophysical properties of human $\mathrm{V}_{\mathrm{H}}$ domains. Protein Eng Des Sel 25:581-589

Kim DY, Hussack G, Kandalaft H, Tanha J (2014) Mutational approaches to improve the biophysical properties of human single-domain antibodies. Biochim Biophys Acta 1844:1983-2001
Loo VG, Poirier L, Miller MA, Oughton M, Libman MD, Michaud S, Bourgault AM, Nguyen T, Frenette C, Kelly M, Vibien A, Brassard P, Fenn S, Dewar K, Hudson TJ, Horn R, René P, Monczak Y, Dascal A (2005) A predominantly clonal multi-institutional outbreak of Clostridium difficile-associated diarrhea with high morbidity and mortality. N Engl J Med 353:2442-2449

Lynch SV, Wiener-Kronish JP (2008) Novel strategies to combat bacterial virulence. Curr Opin Crit Care 14:593-599

MacCannell DR, Louie TJ, Gregson DB, Laverdiere M, Labbe AC, Laing F, Henwick S (2006) Molecular analysis of Clostridium difficile PCR ribotype 027 isolates from Eastern and Western Canada. J Clin Microbiol 44:2147-2152

Mauri PL, Pietta PG, Maggioni A, Cerquetti M, Sebastianelli A, Mastrantonio P (1999) Characterization of surface layer proteins from Clostridium difficile by liquid chromatography/electrospray ionization mass spectrometry. Rapid Commun Mass Spectrom 13: 695-703

Merrigan MM, Venugopal A, Roxas JL, Anwar F, Mallozzi MJ, Roxas BA, Gerding DN, Viswanathan VK, Vedantam G (2013) Surfacelayer protein A (SlpA) is a major contributor to host-cell adherence of Clostridium difficile. PLoS One 8:e78404

Monot M, Boursaux-Eude C, Thibonnier M, Vallenet D, Moszer I, Medigue C, Martin-Verstraete I, Dupuy B (2011) Reannotation of the genome sequence of Clostridium difficile strain 630. J Med Microbiol 60:1193-1199

Ni Eidhin DB, O’Brien JB, McCabe MS, Athie-Morales V, Kelleher DP (2008) Active immunization of hamsters against Clostridium difficile infection using surface-layer protein. FEMS Immunol Med Microbiol 52:207-218

O'Brien JB, McCabe MS, Athie-Morales V, McDonald GS, Ni Eidhin DB, Kelleher DP (2005) Passive immunisation of hamsters against Clostridium difficile infection using antibodies to surface layer proteins. FEMS Microbiol Lett 246:199-205

Pantosti A, Cerquetti M, Viti F, Ortisi G, Mastrantonio P (1989) Immunoblot analysis of serum immunoglobulin $\mathrm{G}$ response to surface proteins of Clostridium difficile in patients with antibioticassociated diarrhea. J Clin Microbiol 27:2594-2597

Péchiné S, Janoir C, Boureau H, Gleizes A, Tsapis N, Hoys S, Fattal E, Collignon A (2007) Diminished intestinal colonization by Clostridium difficile and immune response in mice after mucosal immunization with surface proteins of Clostridium difficile. Vaccine 25:3946-3954

Pépin J, Valiquette L, Alary ME, Villemure P, Pelletier A, Forget K, Pépin $\mathrm{K}$, Chouinard D (2004) Clostridium difficile-associated diarrhea in a region of Québec from 1991 to 2003: a changing pattern of disease severity. CMAJ 171:466-472

Pépin J, Saheb N, Coulombe MA, Alary ME, Corriveau MP, Authier S, Leblanc M, Rivard G, Bettez M, Primeau V, Nguyen M, Jacob CE, Lanthier L (2005) Emergence of fluoroquinolones as the predominant risk factor for Clostridium difficile-associated diarrhea: a cohort study during an epidemic in Québec. Clin Infect Dis 41:1254-1260

Riazi A, Strong PC, Coleman R, Chen W, Hirama T, van Faassen H, Henry M, Logan SM, Szymanski CM, Mackenzie R, Ghahroudi MA (2013) Pentavalent single-domain antibodies reduce Campylobacter jejuni motility and colonization in chickens. PLoS One 8:e83928

Ryan A, Lynch M, Smith SM, Amu S, Nel HJ, McCoy CE, Dowling JK, Draper E, O'Reilly V, McCarthy C, O'Brien J, Ni Eidhin D, O'Connell MJ, Keogh B, Morton CO, Rogers TR, Fallon PG, O'Neill LA, Kelleher D, Loscher CE (2011) A role for TLR4 in Clostridium difficile infection and the recognition of surface layer proteins. PLoS Pathog 7:e1002076

Saerens D, Conrath K, Govaert J, Muyldermans S (2008) Disulfide bond introduction for general stabilization of immunoglobulin heavychain variable domains. J Mol Biol 377:478-488

Sara M, Sleytr UB (2000) S-Layer proteins. J Bacteriol 182:859-868 
Schmidt C, Löffler B, Ackermann G (2007) Antimicrobial phenotypes and molecular basis in clinical strains of Clostridium difficile. Diagn Microbiol Infect Dis 59:1-5

Sebaihia M, Wren BW, Mullany P, Fairweather NF, Minton N, Stabler R, Thomson NR, Roberts AP, Cerdeño-Tárraga AM, Wang H, Holden MT, Wright A, Churcher C, Quail MA, Baker S, Bason N, Brooks K, Chillingworth T, Cronin A, Davis P, Dowd L, Fraser A, Feltwell T, Hance Z, Holroyd S, Jagels K, Moule S, Mungall K, Price C, Rabbinowitsch E, Sharp S, Simmonds M, Stevens K, Unwin L, Whithead S, Dupuy B, Dougan G, Barrell B, Parkhill J (2006) The multidrug-resistant human pathogen Clostridium difficile has a highly mobile, mosaic genome. Nat Genet 38:779-786

Sleytr UB, Beveridge TJ (1999) Bacterial S-layers. Trends Microbiol 7: 253-260

Spigaglia P, Barbanti F, Mastrantonio P (2008) Tetracycline resistance gene tet $(\mathrm{W})$ in the pathogenic bacterium Clostridium difficile. Antimicrob Agents Chemother 52:770-773

Spigaglia P, Galeotti CL, Barbanti F, Scarselli M, Van Broeck J, Mastrantonio P (2011) The LMW surface-layer proteins of Clostridium difficile PCR ribotypes 027 and 001 share common immunogenic properties. J Med Microbiol 60:1168-1173

Stabler RA, He M, Dawson L, Martin M, Valiente E, Corton C, Lawley TD, Sebaihia M, Quail MA, Rose G, Gerding DN, Gibert M, Popoff MR, Parkhill J, Dougan G, Wren BW (2009) Comparative genome and phenotypic analysis of Clostridium difficile 027 strains provides insight into the evolution of a hypervirulent bacterium. Genome Biol 10:R102

Takumi K, Susami Y, Takeoka A, Oka T, Koga T (1991) S layer protein of Clostridium tetani: purification and properties. Microbiol Immunol 35:569-575

Tanha J, Dubuc G, Hirama T, Narang SA, MacKenzie CR (2002) Selection by phage display of llama conventional $V_{H}$ fragments with heavy chain antibody $\mathrm{V}_{\mathrm{H}} \mathrm{H}$ properties. J Immunol Methods 263:97109

To R, Hirama T, Arbabi-Ghahroudi M, MacKenzie R, Wang P, Xu P, Ni F, Tanha $\mathrm{J}$ (2005) Isolation of monomeric human $\mathrm{V}_{\mathrm{H}} \mathrm{S}$ by a phage selection. J Biol Chem 280:41395-41403
Twine SM, Reid CW, Aubry A, McMullin DR, Fulton KM, Austin J, Logan SM (2009) Motility and flagellar glycosylation in Clostridium difficile. J Bacteriol 191:7050-7062

van der Vaart JM, Pant N, Wolvers D, Bezemer S, Hermans PW, Bellamy K, Sarker SA, van der Logt CP, Svensson L, Verrips CT, Hammarstrom L, van Klinken BJ (2006) Reduction in morbidity of rotavirus induced diarrhoea in mice by yeast produced monovalent llama-derived antibody fragments. Vaccine 24:4130-4137

Virdi V, Coddens A, De Buck S, Millet S, Goddeeris BM, Cox E, De Greve H, Depicker A (2013) Orally fed seeds producing designer IgAs protect weaned piglets against enterotoxigenic Escherichia coli infection. Proc Natl Acad Sci U S A 110:11809-11814

Warny M, Pépin J, Fang A, Killgore G, Thompson A, Brazier J, Frost E, McDonald LC (2005) Toxin production by an emerging strain of Clostridium difficile associated with outbreaks of severe disease in North America and Europe. Lancet 366:1079-1084

Waseh S, Hanifi-Moghaddam P, Coleman R, Masotti M, Ryan S, Foss M, MacKenzie R, Henry M, Szymanski CM, Tanha J (2010) Orally administered P22 phage tailspike protein reduces Salmonella colonization in chickens: prospects of a novel therapy against bacterial infections. PLoS One 5:e13904

Wesolowski J, Alzogaray V, Reyelt J, Unger M, Juarez K, Urrutia M, Cauerhff A, Danquah W, Rissiek B, Scheuplein F, Schwarz N, Adriouch S, Boyer O, Seman M, Licea A, Serreze DV, Goldbaum FA, Haag F, Koch-Nolte F (2009) Single domain antibodies: promising experimental and therapeutic tools in infection and immunity. Med Microbiol Immunol 198:157-174

Yang Z, Schmidt D, Liu W, Li S, Shi L, Sheng J, Chen K, Yu H, Tremblay JM, Chen X, Piepenbrink KH, Sundberg EJ, Kelly CP, Bai G, Shoemaker CB, Feng H (2014) A novel multivalent, singledomain antibody targeting TcdA and TcdB prevents fulminant Clostridium difficile infection in mice. J Infect Dis 210:964-972

Yau KY, Dubuc G, Li S, Hirama T, Mackenzie CR, Jermutus L, Hall JC, Tanha J (2005) Affinity maturation of a $\mathrm{V}_{\mathrm{H}} \mathrm{H}$ by mutational hotspot randomization. J Immunol Methods 297:213-224

Zabetakis D, Olson MA, Anderson GP, Legler PM, Goldman ER (2014) Evaluation of disulfide bond position to enhance the thermal stability of a highly stable single domain antibody. PLoS One 9:e115405 